\title{
The Economic Consequences of Increased Disclosure: Evidence From International Cross-Listings
}

\author{
Warren B. Bailey \\ G. Andrew Karolyi \\ University of Pennsylvania \\ Carolina Salva
}

Follow this and additional works at: https://repository.upenn.edu/accounting_papers

Part of the Accounting Commons

\section{Recommended Citation}

Bailey, W. B., Karolyi, G., \& Salva, C. (2006). The Economic Consequences of Increased Disclosure: Evidence From International Cross-Listings. Journal of Financial Economics, 81 (1), 175-213.

http://dx.doi.org/10.1016/j.jfineco.2005.06.002

Andrew Karolyi was affiliated with the University of Pennsylvania at the time of publication but he is currently a faculty member at Cornell University.

This paper is posted at ScholarlyCommons. https://repository.upenn.edu/accounting_papers/101

For more information, please contact repository@pobox.upenn.edu. 


\title{
The Economic Consequences of Increased Disclosure: Evidence From International Cross-Listings
}

\begin{abstract}
We examine market behavior around earnings announcements to understand the consequences of the increased disclosure that non-U.S. firms face when listing shares in the U.S. We find that absolute return and volume reactions to earnings announcements typically increase significantly once a company crosslists in the U.S. Furthermore, these increases are greatest for firms from developed countries and for firms that pursue over-the-counter listings or private placements, which do not have stringent disclosure requirements. Additional tests support the hypothesis that it is changes in the individual firm's disclosure environment, rather than changes in its market liquidity, ownership, or trading venue, that explain our findings.
\end{abstract}

\section{Keywords}

international cross-listing, earnings announcements, trading volume, volatility

Disciplines

Accounting

\section{Comments}

Andrew Karolyi was affiliated with the University of Pennsylvania at the time of publication but he is currently a faculty member at Cornell University. 


\title{
The Economic Consequences of Increased Disclosure: Evidence from International Cross-listings
}

\author{
Warren Bailey, G. Andrew Karolyi, and Carolina Salva *
}

Cornell University, Ohio State University, and Instituto de Empresa

7 December 2000

Current version: 13 March 2002

\begin{abstract}
We study return volatility and trading volume at times of earnings announcements to see if the increased disclosure faced by non-U.S. firms when listing shares in the U.S. has economically significant consequences. We find a surprising change in market behavior around earnings releases: return and volume reactions to earnings announcements typically increase significantly once a stock cross-lists in the U.S. Furthermore, the change in information environment is greatest for firms from developed countries and firms that do not list on an organized stock exchange. The increased market reaction to earnings shocks after cross listing is particularly prominent for firms from developed countries with relatively weak disclosure requirements.
\end{abstract}

JEL Classification: G14, G15, G32

Keywords: International cross-listing, earnings announcements, trading volume, volatility

* Corresponding author: Warren Bailey, Cornell, Johnson Graduate School of Management, Cornell University, Sage Hall, Ithaca, NY 14853-6201, 607-255-4627, fax 607-255-4627, wbb1@cornell.edu. We thank Craig Doidge, Peter Easton, Wayne Ferson, Ed Kane, Connie X. Mao, René Stulz, Kent Womack, and workshop participants at INSEAD, Georgetown, ESSEC, Universidade Nova de Lisboa, and Boston College for helpful discussions, comments on earlier drafts, and other assistance. We are grateful to $\mathrm{I} / \mathrm{B} / \mathrm{E} / \mathrm{S}$ for permission to use their earnings database and the Dice Center for Financial Economics at Ohio State for financial support (Karolyi). The paper has previously circulated under the title: "Market Segmentation and the Capital Market Reaction to Earnings Announcements: Evidence from International CrossListings."

(C) 2002 Warren Bailey, G. Andrew Karolyi, and Carolina Salva. 


\section{Introduction}

When firms commit to increased levels of disclosure, the potential for information asymmetries to arise between the management of the firm and its shareholders or among buyers and sellers of the firm's shares diminishes. There are many reasons why a firm would choose to reduce information asymmetry by increasing disclosure. Managers who anticipate making capital market transactions (issuing public debt or equity or acquiring another company in a stock transaction) have incentives to provide voluntary disclosure to reduce the information risk borne by investors which, in turn, reduces the firm's cost of external financing. ${ }^{1}$ Firms with high levels of disclosure are also more likely attract investors who are more confident that stock transactions occur at "fair" prices, thereby increasing the liquidity in the stock (Diamond and Verrecchia, 1991; Kim and Verrecchia, 1991a, 1991b, 1994). Voluntary disclosure can also lower the cost of information acquisition for analysts and hence increase their supply. ${ }^{2}$

Most of the empirical evidence on the economic consequences of increased disclosure has focused on U.S. firms with publicly registered securities under current U.S. Generally Accepted Accounting Principles (GAAP). The disclosure environment is already rich, so that commitments to increased levels of disclosure have limited economic impact. In contrast, the disclosure levels mandated by securities market regulators in many countries around the world have been criticized as relatively low (Decker, 1994; Rader, 1994). One important context in which international differences in disclosure standards matter is when non-U.S. firms choose to list their shares on U.S. exchanges or register their securities with the S.E.C. for a public offering of shares to U.S. investors. There are, of course, many reasons why a firm may choose to list

\footnotetext{
${ }^{1}$ See Barry and Brown (1984, 1985), Myers and Majluf (1984), Merton (1987), and Healy and Palepu, (1993, 2001)

${ }^{2}$ See Bhushan (1989), Rajan and Servaes (1997), Lang and Lundholm (1996), Healy,Hutton, and Palepu (1999). The ability to signal management or firm quality (Admati and Pfleiderer, 2000), concerns about litigation risk from delayed disclosure and the importance of stock-based compensation contracts for managers are other potential motives (Healy and Palepu, 2001).
} 
shares in the U.S. including access to capital, greater liquidity, lower cost of capital and corporate prestige. However, surveys of corporate managers about the decision to list in the U.S. most often cite the process of reconciling home-country and U.S. reporting and disclosure standards as a substantial challenge. ${ }^{3}$ For example, Fanto and Karmel (1997) report that three of the top six "difficulties" experienced in a U.S. listing include accounting reconciliation (cited by 15 percent of listing managers, 21 percent of non-listing managers), preparation of Management Discussion and Analysis (10 percent listed, 7 percent unlisted) and segment reporting (6 percent listed, 11 percent unlisted). Notwithstanding these difficulties, there has been a huge increase in the number of non-U.S. firms listing on U.S. markets through public offerings on the NYSE, Amex, and Nasdaq and through over-the-counter (OTC) listings on the OTC Bulletin Board, "pink sheets," and even private placements by means of S.E.C. Rule 144a offerings.

The objective of this study is to evaluate the economic impact of the increased disclosure faced by non-U.S. firms when they list their shares on U.S. markets. Specifically, we examine the price volatility and volume reactions to earnings announcements by these firms before and after their U.S. listing. To this end, we assemble a sample of 2,695 earnings announcement events for 427 firms from over 40 emerging and developed markets around the world. We compare the volatility and volume reactions to earnings announcements before and after the U.S. listing and relate these differences to firm, industry, and country level attributes. Our motivation to examine capital market reactions to earnings announcements stems from the analytical and empirical studies that emphasize the role of information asymmetry and differential information processing by investors in evaluating those reactions. ${ }^{4}$ These studies show how the volume

\footnotetext{
${ }^{3}$ It is also cited as a great challenge for U.S. based investors diversifying their portfolios into international markets. See "Cherchez la footnote" Forbes (December 24, 2001).

4 The seminal studies in this area include Diamond and Verrecchia (1991) Kim and Verrecchia, (1991a, 1991b, 1994), Harris and Raviv (1993) and Kandel and Pearson (1995).
} 
reaction to an earnings announcement is an increasing function of both the magnitude of the price reaction and the level of information asymmetry among investors. How the volume and volatility reactions to earnings announcements change after non-U.S. firms list in the U.S. can help us to infer how the quality of the information environment has been affected. If, for example, we find that the reactions diminish upon listing, one could infer that the prior information among investors is now of higher quality, generating less noise and lower residual uncertainty. Alternatively, volume and volatility reactions could arise if the costs of information acquisition are lower, yielding more analyst coverage of the stock and allowing more precise private information to be incorporated into prices. Finally, this outcome could arise if there is less disagreement among investors in interpreting the information content of the public announcement or less asymmetry of private information among investors.

Two unique aspects of this setting make our experiment particularly useful and help us to contribute to the literature on increased disclosure. First, disclosure standards and other capital market characteristics differ widely across countries. The disparity between local and U.S. GAAP should be particularly great for companies from emerging economies with poor disclosure standards. Our sample of listings affords us a rich cross-section of countries with which to relate the capital market reactions we uncover to the degree of increased disclosure the firm faces. Volume and volatility reactions around earnings announcements should be larger for those companies from emerging economies or those with weaker disclosure standards. Second, our sample includes U.S. listings on major exchanges, OTC markets as well as private placements. Full reconciliation with U.S. GAAP is required only for exchange listings; the disclosure standards are lower for OTC listings and are minimal for 144a private placements. This range of choices for a U.S. listing allows us as researchers to isolate the capital market effects of listing from that associated with increased disclosure. Firms that list in the U.S. 
through private placement offerings should experience no significant change in volume/volatility reactions to earnings due to increased disclosure.

Recent studies have uncovered significant, positive share price reactions associated with U.S. listings by non-U.S. companies and have proposed different hypotheses to explain these findings. ${ }^{5}$ Our study also contributes to this literature, as few previous authors have focused on the importance of the change in the information environment. Foerster and Karolyi (1999) and Miller (1999) find statistically significant share price effects around U.S. listings and show how these effects are consistent with the "investor recognition" hypothesis of Merton (1987). The hypothesis proposes that investors pay a premium for familiar assets: a U.S. listing exposes more shareholders to those shares, the "unfamiliarity discount" dissipates, and stock prices increase. Unfortunately, these studies do not evaluate and, at best, only indirectly control for the change in the information environment. Baker, Nofsinger and Weaver (2001) show that U.S. listings by non-U.S. firms are associated with greater visibility with significant increases in the number of analysts following the stock and the number of media "hits." However, they do not evaluate the economic impact of the change in visibility. Finally, there are several analytical models of the U.S. listing decision that relate to disclosure requirements (Cantale, 1998, Fuerst, 1998; Moel, 1999; Huddart, Hughes and Brunnermeier, 1999). These models predict that larger, higher quality firms in low-disclosure-quality environments will optimally disclose more information and experience a capital gain at the time of listing as a reward for signaling their higher quality

\footnotetext{
5 Alexander, Eun and Janakiramanan (1987, 1988), Foerster and Karolyi (1999), and Miller (1999) argue that magnitude of investment barriers and the international segmentation of capital markets can explain the price effects. Lins, Strickland and Zenner (2000) emphasize the greater liquidity and efficiency of U.S. capital markets. Coffee (1999), Stulz (1999), Reese and Weisbach (2001) and Doidge (2001) focus on the better legal protection for minority shareholders provided by U.S. securities law. Doidge, Karolyi and Stulz (2001) argue that the higher valuation of non-U.S. firms listed on U.S. markets can be explained by the high agency costs of controlling shareholders. Karolyi (1998) surveys this literature. Salva (2000) studies non U.K. firms that list in the U.K.
} 
relative to peers that do not list. Only Moel provides some empirical support and only regarding the likelihood of listing, not price effects.

We find a pronounced impact of the increased disclosure faced by non-U.S. firms after they list in the U.S. Surprisingly, the abnormal return volatility and trading volume in the home market around earnings announcements are significantly higher in the period following the listing than in the period before the listing. Moreover, we find that the most dramatic increase occurs for those firms that list from developed markets and those that do not list on a major exchange. The increased market reaction to earnings shocks after cross listing is particularly prominent for firms from developed countries with relatively weak disclosure requirements. We interpret these results in the context of theoretical and empirical work on the economic effects of increased disclosure and, especially, those studies that focus on the market reaction to the public announcement of earnings. To the extent that our results are not consistent with the predictions of these models, we explore alternative interpretations and explanations.

In the next section, we discuss the institutional and theoretical background and outline the main hypotheses. Section 3 describes the data and empirical methodology. Results are presented in section 4. We conclude the paper discussing alternative interpretations of our findings and implications for further research and for policymakers.

\section{Theory and Hypotheses}

\subsection{Capital Market Reactions to Earnings Announcements}

The market's reaction to the public announcement of earnings has been one of the primary streams of research in the accounting literature. While much of the work has focused on price reactions, others have also examined trading volume and the relation between volume and price reactions for what it reveals about the market's reaction to increased disclosure. The 
seminal analytical studies by Diamond and Verrecchia (1991), Kim and Verrecchia (1991a, 1991b, 1994) establish the intuition that trading volume reactions reflect differences among individual investors in the price formation process. The differences stem from information asymmetry which arise when investors acquire private information and the quality (precision) of the private information differs. Specifically, they show that trading volume reactions to public announcements, like earnings, is an increasing function of the magnitude of the price reaction and the level of information asymmetry among investors. When new information, such as earnings, is announced, investors with more precise private information will make smaller revisions of expected value of the stock than less-informed investors with less precise private information. The differential revisions of expected value generate trading volume. Trading volume and absolute price changes reflect the average change in investors' expectations which is related to the economic importance of the public information, but trading volume also reflects differences among investors' expectations revisions due to information asymmetry.

Empirical work on volume and volatility reactions to earnings announcements has validated these basic predications. ${ }^{6}$ Atiase and Bamber (1994), for example, compute two empirical proxies for information asymmetry using the dispersion and range in analysts earning forecasts. They find that both proxies are significantly positively related to trading volume reactions to earnings announcements, even after controlling for the magnitude of the associated price reaction. In our paper, we will follow the same basis for our key hypotheses that the magnitude of trading volume reactions to earnings announcements is positively related to both the associated price volatility and the level of information asymmetry. We will also control for information asymmetry using one of the same proxies (disperson of analyst forecasts), but, in

\footnotetext{
${ }^{6}$ See Atiase and Bamber (1994), Bamber and Cheon (1995), Abarbanell, Lanen and Verrecchia (1995), Utama and Cready (1997), Kim, Krinsky and Lee (1997), and Barron and Stuerke (1998). The survey studies by Healy and Palepu (2001) and Verrecchia (2001) cite a number of these empirical papers.
} 
comparing the volume and volatility reactions before and after the U.S. listing, we seek to detect changes in the information environment. If the quality (precision) of the prior private information is greater or if the costs of information acquisition are lower after listing on U.S. markets, we expect less residual uncertainty and lower absolute abnormal returns around earnings announcements. With less information asymmetry (ceteris paribus), we also expect lower abnormal volume reactions.

Volume and volatility reactions to public earnings announcements can be understood in terms of differences across investors in interpreting public announcements instead of asymmetry of private information. Grundy and McNichols (1989), Harris and Raviv (1993), He and Wang (1995) and Kandel and Pearson (1995) propose that volume reflects differences in opinion among speculative investors. ${ }^{7}$ Kandel and Pearson specifically use the example of earnings announcements to show that significant positive abnormal volume can arise even when there is no change in valuation in response to the announcements. They also show that forecast revisions among analysts around earnings are frequent and sizable, which they argue is consistent with different likelihood functions to interpret public announcements. Bessembinder, Chan and Seguin (1996) test these models using open interest in S\&P 500 index futures contracts as a proxy for divergences in traders' opinions to forecast market volume and volume on individual equities.

\subsection{International Cross-listings and Disclosure Issues}

Our study includes international cross-listings of all forms, including American Depositary Receipts (ADRs), ordinary listings, and even global registered shares (GRSs). Almost

\footnotetext{
${ }^{7}$ There is a new literature that focuses on volume as a source of information about firm value, rather than explaining volume as a consequence of asymmetry of private information signals or differences of opinion. Important contributions include Campbell, Grossman and Wang (1993), Blume, Easley and O'Hara (1994), Wang (1994) and Kim and Verrecchia (2001). Chapter 6 of O'Hara (1997) synthesizes these different strands of the literature.
} 
all non-U.S. companies that list their shares on U.S. exchanges do so by creating ADRs. ADRs are investment vehicles for investors to register and earn dividends on non-U.S. stock without direct access to the overseas market itself. U.S.-based depositary banks hold the overseas securities in custody in the country of origin and convert all dividends and other payments into U.S. dollars for receipt holders. Each receipt represents shares in the home market and new receipts can be created by the bank for investors when the requisite number of shares are deposited in their custodial account. Cancellations of ADRs reverse the process.

There are many advantages to ADRs for issuers including an enlarged investor base, access to capital, greater liquidity, and corporate prestige. At the same time, non-U.S. companies must satisfy two requirements to be listed in the U.S. First, they must arrange with a transfer agent and registrar appropriate settlement facilities that can coordinate with the home market. Second, to register with the S.E.C., the company must file a registration statement and furnish an annual report on a Form 20-F with a reconciliation with U.S. GAAP. There are several options for issuers to balance these advantages and costs. Level 1 ADRs trade over-the-counter on the OTC Bulletin Board or as a "pink sheet" issue with limited liquidity, but they require only minimal SEC disclosure and no GAAP reconciliation (exempt from Form 20-F by Rule 12g32(b) exemption. Level 2 and 3 ADRs are exchange-listed securities and they require full SEC disclosure with Form 20-F, a "current events" Form 6K which can include extensive information and compliance with the exchange's own listing rules. ${ }^{8}$ Level 3 programs raise capital and must be associated with Form F-2 and F-3 filings for offerings. Finally, S.E.C. Rule 144a issues raise capital as private placements to qualified institutional buyers (QIBs) and, as a result, do not require compliance with GAAP. These 144a programs trade on the PORTAL system with very

\footnotetext{
${ }^{8}$ The NYSE, for example, also requires semi-annual reports by home country GAAP and encourages quarterly reports as well.
} 
limited liquidity. Table 1 summarizes these differences in registration, reporting and disclosure requirements. ${ }^{9}$

Ordinary listings and GRSs represent important alternatives to ADRs for cross-listings in the U.S. Ordinary listings require an exact replication of settlement facilities as for U.S. securities and go beyond Level 2 and Level 3 ADRs in requiring full annual and quarterly reports prepared in accordance with U.S. GAAP. ${ }^{10}$ The GRS was introduced with newly-merged DaimlerChrysler (DCX) in November 1998 and is employed today by Deutsche Bank, Celanese and UBS. A GRS does not require an intermediary receipt like an ADR but does require a coordination of the transfer agent, clearance and settlement procedures in the U.S., home and other overseas markets (Karolyi, 2001). Disclosure standards are equivalent to Level 2 and 3 ADRs; DCX, for example, files an annual 20F. In our study of disclosure standards, we treat ordinary listings and GRSs as equivalent to exchange-listed ADRs.

There is a large literature on international cross-listings (Karolyi, 1998). Much of the early work was built using the insights of international asset pricing models with barriers to international investment. ${ }^{11}$ In these models, a firm located in a country that is not fully integrated in the world markets typically faces a higher cost of capital because its risk has to be borne mostly by investors from its country. If the firm finds a way to make it less costly for foreign investors to hold its shares, these investors share the risk, the cost of capital falls and the firm's stock price increases. A U.S. listing is a way for firms to finesse segmenting barriers and to make

\footnotetext{
${ }^{9}$ Details are available from the three main depositary banks: Bank of New York (www.bankofny.com), JP Morgan (www.adr.com) and Citibank (wwss.citissb.com/adr/www).

${ }^{10}$ Canadian firms use ordinary listing rather than ADRs and can use Canadian GAAP that is very similar to U.S. GAAP as permitted by the Multi-Jurisdictional Disclosure System since 1991. See Multi-Jurisdictional Disclosure and Modifications to the Current Registration and Reporting System for Canadian Issues, Securities Act Release No. 6902 (July 1, 1991) and Foerster and Karolyi (1993, 1998). Among non-Canadian firms in our sample, ordinary listings are very unusual, as are changes between ordinary listings and ADR programs.

${ }^{11}$ Black (1974), Stapleton and Subrahmanyam (1977), and Stulz (1981) lay the groundwork for papers by Errunza and Losq (1985) and Alexander, Eun and Janakiramanan (1987) to develop equilibrium models of the repricing of shares of firms cross-listing abroad.
} 
their shares more accessible to foreign investors. The empirical findings of Alexander, Eun and Janakiramanan (1988), Foerster and Karolyi (1993, 1999), Miller (1999) find statistically significant and positive stock price reactions to U.S. listing announcements and listings consistent with the predictions from this market segmentation hypothesis.

Newer evidence suggests that there may be other forces at work. Foerster and Karolyi (1999) show that the share price effects and risk changes around listings are associated with changes in the shareholder base and interpret their findings in the context of Merton's (1987) investor recognition hypothesis. Investors are presumed to invest only in familiar stocks and are priced to include an incompleteness premium; when they list in the U.S., this incompleteness premium dissipates and the stock price increases. Lins, Strickland and Zenner (2000) suggest that firms that list in the U.S. gain value because they bypass local underdeveloped markets to access the greater liquidity and efficiency of U.S. markets. Cantale (1996), Fuerst (1998) and Moel (1999) establish a signaling equilibrium in which firms try to communicate their private information regarding their quality to outside investors by listing their shares in overseas markets. Their hypothesis presumes that the credibility of the signal of quality stems from the higher level of information disclosure required by the U.S. Coffee (1999), Stulz (1999), Reese and Weisbach (2001) and Doidge, Karolyi and Stulz (2001) argue that a U.S. listing and thus U.S. securities law enhances the protection of investors for firms coming from poor investor protection countries, thereby reducing the agency costs of controlling shareholders and the risk of expropriation.

Few, if any, of these studies focus on or attempt to measure directly the value relevance of increased disclosure associated with U.S. listings. Instead, they measure large share price effects around listings and seek to associate them with proxies that relate to the various hypotheses. It is important to recognize a growing accounting literature that focuses on the value 
relevance of international accounting harmonization. Analytical studies by Huddart, Hughes and Brunnermeier (1999) and Barth, Clinch and Shibano (1999) establish the conditions under which firms will list based on the optimal disclosure standards defined by the exchanges or in terms of the benefits and costs of foreign analysts becoming experts in local market GAAP. Empirical work has explored these issues by focusing on the relative informativeness of accounting disclosures in different countries (Alford, Jones, Leftwich and Zmijewski, 1993) and the differential response of stock prices to earnings disclosed in overseas and local markets (Frost and Pownall, 1994). A number of more recent studies have examined stock price reactions to Form 20-F reconciliations by foreign firms listing in the U.S. or voluntary reconciliations to international accounting standards (IAS). ${ }^{12}$

\subsection{Key Hypotheses}

We structure our empirical tests around several hypotheses implied by the theoretical literature. The models of Kim and Verrecchia (1991a, 1991b, 1994), Harris and Raviv (1993), and Kandel and Pearson (1995) show that trading volume and price reactions to earnings announcements are complex. The reactions depend on the information content of the public announcement, the quality of the prior information, the cost of information acquisition and the dispersion in investors' opinions or the degree of private information asymmetry. Our first hypothesis focuses on how the information environment of the firm affects the price volatility around earnings announcements. The magnitude of the price reaction stems from the average change in investors' beliefs and this, in turn, depends on the magnitude of the surprise and the

\footnotetext{
${ }^{12}$ Amir, Harris and Venuti (1993), Chan and Seow (1996), Rees and Elgers (1997), Alford and Jones (1998), Harris and Muller (1999) and Karamanou and Raedy (2001) are useful examples of this literature. Rader (1994), Ruder (1996), and Fox (1998) focus on the political challenges of reconciling U.S. disclosure policy with international accounting standards. Leuz and Verrecchia (2000) and Leuz (2001) demonstrate significant differences in bid-ask spread and trading volume between German firms that reconcile with IAS or U.S. GAAP and those that retain German reporting standards.
} 
precision of the announcement relative to the average precision of investors' total information. If the quality of the information environment improves after listing in the U.S. because of the more stringent disclosure requirements, the costs of information acquisition would decline, more analysts would cover the stock, and the precision of the prior private information is greater.

Hypothesis 1: The abnormal absolute price change around the earnings announcement is lower following a listing in the U.S. for a company that faces increased disclosure requirements.

We want to isolate whether the U.S. listing improves the quality of the information environment with greater precision of, and less residual uncertainty about, the information content of the announcement. As a result, we attempt to control for the magnitude of the earnings surprise (deviation of actual earnings from median analyst forecast) and the change in the number of analysts who cover the stock. Most importantly, we control for the type of U.S. listing pursued by the company and the rigor of home-country accounting and disclosure standards to capture the magnitude of the change in the information environment. For companies that choose exchange listings (ordinary listings, GRSs, Level 2 or 3 ADRs) and for those that list in the U.S. from countries with relatively poor accounting standards, we expect a more dramatic decrease in abnormal absolute price changes around earnings announcements than that for companies that choose OTC listings or Rule 144a private placements and for those that list from countries with relatively good accounting standards. As a result, we offer the supplementary hypothesis:

Hypothesis 1a: The decrease in abnormal absolute price change around the earnings announcement following a listing in the U.S. is greater for those companies that choose listings that require full reconciliation with U.S. GAAP and disclosure standards (Level 2/3 ADRs, ordinary listings, GRSs) and for those companies from countries with less-developed economies and weaker accounting systems. 
The trading volume reaction to an earnings announcement is proportional to the magnitude of the associated price reaction and the level of private information asymmetry or public information disagreement among investors. Our second hypothesis positively links the abnormal trading volume around earnings announcements to the degree of information asymmetry or disagreement, given the magnitude of the associated price reaction:

Hypothesis 2: The abnormal trading volume around the earnings announcement is lower (higher) following a listing in the U.S. for a company that faces increased disclosure requirements, if there is less (more) information asymmetry or disagreement among investors.

The key to testing this second hypothesis is not only to isolate the magnitude of the absolute price change, but also to control for the information asymmetry or disagreement. To this end, we construct a proxy based on the number of analysts and the dispersion of analysts' forecasts. But, our focus, again, is on the type of listing the firm seeks, the level of economic development in the home country and the home-country disclosure standards. For companies that choose exchange listings and for those that list in the U.S. from countries with less-developed economies and relatively poor accounting standards, we expect a more dramatic change in abnormal trading volume around earnings announcements than that for companies that choose OTC listings or Rule 144a private placements and for those that list from countries with relatively good accounting standards. If increased disclosure generates more (less) information asymmetry, the abnormal volume reaction to earnings announcements is greater (lower). Our supplementary hypothesis is as follows:

Hypothesis 2a: The increase (decrease) in abnormal trading volume around the earnings announcement due to more (less) information asymmetry or disagreement among investors is greater for those companies that choose listings that require full reconciliation with U.S. GAAP and disclosure standards (Level 2/3 ADRs, ordinary listings, GRSs) and for those companies from countries with less-developed economies and weaker accounting systems. 


\section{Data and Methodology}

\subsection{Data}

We obtain details of foreign firms listed in the U.S. (NYSE, NASDAQ, AMEX, over-the counter, or 144A) with a depositary receipt (ADR) or ordinary listing from the Bank of New York and other sources. ${ }^{13}$ We restrict the sample using the following criteria. First, the listing date is available. Second, daily closing prices and trading volumes from the home market are available from Datastream International for five years both before and after the U.S. listing. This precludes IPOs as no information is available prior to listing in the U.S. Third, earnings announcement dates, values, and at least one analyst earnings forecast are available from the Institutional Brokers Estimate System (I/B/E/S) records both before and after U.S. listing. ${ }^{14}$

Often a company has several stock types trading in the home market. To identify the underlying stock type to match a DR issue, we use Bloomberg, Bridge, SEC (20-F) filings, and web pages of depositary banks and stock exchanges. If these sources could not help to match the DR or direct listing to the underlying security in the home market, we checked that the pricing relationship between the DR underlying issue and the home market security is reasonably close. ${ }^{15}$ In a few cases, a class of share is created specifically for the U.S. listing so there is no matching issue in the home country. ${ }^{16}$ When this occurs, data are collected for the ordinary type of security listed in the home market.

\footnotetext{
${ }^{13}$ See, for example, www.adrbny.com and www.adr.com. Our sample is biased towards recent events and may exclude DRs that were subsequently delisted or downgraded to a lower level program.

${ }^{14}$ See Atiase and Bamber (1994), Kim, Krinsky and Lee (1997), and Chang, Khanna and Palepu (2000). We do not attempt to follow the accounting literature in, for example, restricting the sample to EPS forecasts greater that $\$ 0.10$ since EPS in our context is reported in many different currencies.

${ }^{15}$ Generally, arbitrage ensures insignificant differences between ADR and underlying share prices once the ADR ratio and exchange rate are accounted for. Kato, Linn, and Schallheim (1991), Park and Tavakkol (1994), and Miller and Morey (1996) offer supporting evidence for this claim.

${ }^{16}$ This may arise due to foreign ownership restrictions imposed by regulatory authorities (Bailey, Chung, and Kang, 1999), or differing dividends or voting rights assigned by companies (Nenova, 2001).
} 
For each stock, daily home market prices and trading volumes are collected from Datastream, as are capitalization, local market indices and exchange rates. When possible, we obtain return and trading volume information for all five years before and after the first listing date in the US. However, the available time series are often shorter. When a security is not listed in the firm's country of incorporation, prices and trading volumes are taken from the stock's primary market.

Earnings announcements and forecasts are collected from the Institutional Brokers Estimate System (I/B/E/S) tapes. The frequency of earnings information releases varies through countries and firms. For cross-country consistency, we use annual earnings announcements: they maximize the number of events over the widest range of countries. The earnings surprise equals the difference between actual earnings and the mean of the most recent analyst forecasts normalized by the mean forecast. To calculate the mean forecast, we take the last estimate for each analyst reporting forecasts for the current fiscal year.

Table 2 summarizes the number of firms and number of earnings events in the sample by country and by U.S. exchange. While there are large numbers of firms from developed countries such as Canada (42) and the U.K. (49), there are surprisingly large numbers of firms from developing countries such as Brazil (23), India (28), and Mexico (10). The geographical dispersion of the countries is also high and helps increase variability in pre-listing information environments across countries. The number of earnings events ranges from just a handful for China and Indonesia to over a hundred for Canada, Hong Kong, and the U.K. The majority of firms are listed either over-the-counter (207) or as 144a (85), rather than on the NYSE (97), NASDAQ (26), or AMEX (2). Again, this offers us a broad cross-section of listing characteristics for empirical study. Interestingly, emerging-market firms are most likely to establish Rule 144a private placement programs while developed-country firms typically use the 
higher-level over-the-counter route or formal listing on an exchange. Table 1 also reports an indicator of the quality of accounting standards in each country, the index produced by the Center for International Financial Analysis and Research and used by La Porta, Lopez-deSilanes, Shleifer and Vishny (1998) that scores annual reports based on inclusion or omission of 90 key items. ${ }^{17}$ The range of accounting standard index values (from a low of 36 for Portugal to a high of 83 for Sweden) confirms the broad cross section of home country information environments represented in our sample.

\subsection{Event study approach}

Our first tests are event studies performed on returns and trading volumes around an earnings announcement. The estimation window is the interval $(-200,-11)$ with respect to the announcement day, as in existing studies. Following standard methodology as in Brown and Warner (1985), abnormal returns are prediction errors from the market model using the local market index. ${ }^{18}$ Stock and local index returns are log-differences expressed in the home market currency. Given thin trading in some of the stocks, we follow the "trade to trade" approach of Maynes and Rumsey (1993). ${ }^{19}$ Following Kim and Verecchia (1991a), we abstract from the sign of returns and use the absolute value of abnormal returns to measure return volatility. Abnormal volume equals daily volume minus the mean volume over the estimation window $(-200,-11)$ divided by the mean volume. Similar results are obtained with abnormal volume adjusted by the median. To implement hypothesis tests, we use the nonparametric rank test of Corrado (1989) and Corrado and Zivney (1992) who demonstrate that their rank test is preferable in the presence

\footnotetext{
${ }^{17}$ International Accounting and Auditing Trends (4th edition, 1997), Center for International Financial Analysis and Research, Princeton, New Jersey.

${ }^{18}$ Our purpose is to generate residuals using a benchmark that mimics the behavior of local returns as closely as possible. We are not fitting an international asset-pricing model that would probably require us to use a two-factor model with both local and world stock return aggregates.

${ }^{19}$ Results are similar if abnormal returns are computed without controlling for infrequent trading and by restricting the sample to more liquid firms.
} 
of non-normality and asymmetry. ${ }^{20}$ A parametric $t$-test as used by Brown and Warner (1985) is also computed for comparison.

\subsection{Cross-sectional regression tests}

Abnormal returns are cumulated over three $(-1,1)$ day windows and transformed to proxy for return volatility by taking the absolute value. Trading volume is normalized by the mean trading volume and then cumulated over identical three-day event windows. ${ }^{21}$ The absolute abnormal return and trading volume are then regressed on a set of explanatory variables summarized in Table 5 and detailed below.

First, our cross-sectional specifications include several variables adopted from standard practice in the earnings and dividends announcement literature. The absolute value of the earnings surprise (a measure of the precision of information) serves as an explanatory variable in the cross-sectional regression to explain the absolute abnormal return in the event window. The absolute abnormal return serves as an explanatory variable in the cross-sectional regression to explain abnormal trading volume in the event window. Forecast dispersion, a measure of predisclosure information asymmetry (Atiase and Bamber, 1994) and disagreement, equals the standard deviation of analyst forecasts (the last one before the announcement for each analyst) divided by the absolute value of the mean forecast. It serves as an explanatory variable in crosssectional regressions to explain absolute abnormal returns and abnormal trading volume.

Second, we consider the possibility that the reaction to an earnings surprise depends on the sign of the surprise (Hayn, 1995) and construct a dummy variable equal to one for positive earnings surprises and zero otherwise. The number of analyst forecasts used to compute the mean forecast for the particular earnings event proxies for the degree of analyst attention, one

\footnotetext{
${ }^{20}$ Corrado and Zivney (1992) adjust for infrequent trading. When a stock trades daily, their rank statistic is identical to Corrado (1989).

${ }^{21}$ Results computed over seven-day $(-1,5)$ windows for both returns and volume are very similar.
} 
facet of the information environment. If firms signal their quality with a U.S. listing and analysts tend to follow higher quality firms (Chung, 2000; Rajan and Servaes, 1998), the number of analysts following a firm increases after cross listing.

Finally, we construct variables to test our prediction that the change in information environment upon listing in the U.S. will be greatest for firms originating in poor quality environments. The change in information environment upon listing in the U.S. depends on the home country environment of the listing company, which we set equal to the index constructed by La Porta et al $(1998)^{22}$ to rate the quality of information in annual reports across countries. ${ }^{23}$ We assign a dummy variable equal to one for stocks from developed countries and zero, otherwise, according to the classification scheme of the World Bank. ${ }^{24}$ We predict that the change in price and volume reactions to earnings after U.S. listing is greatest for firms from emerging markets with low values of the accounting index.

\section{Results}

We first report the event study tests on the abnormal absolute returns and abnormal trading volume around earnings announcements before and after listing for the full sample and by various event-specific, firm-specific and country-level attributes. The cross-sectional multivariate regression tests follow.

\footnotetext{
${ }^{22}$ La Porta et al (1998) also supply indexes of legal quality and other country characteristics that differ across our sample countries and are strongly correlated with the accounting standards index. While an enhanced legal environment may be one reason that foreign firms seek a U.S. listing or investors value such a listing, our focus is not on legal issues, like Coffee (1999), Stulz (1999), and Reese and Weisbach (2001), but rather on the change in the information environment engendered by a U.S. listing.

${ }^{23}$ See Alford, Jones, Leftwich, and Zmijewski (1993) for a detailed comparison of disclosure standards across developed countries.
} 


\subsection{Event Study Results}

Table 3 presents results of the event study of absolute abnormal returns and abnormal trading volume for the entire sample of 1,273 pre-listing events and 1,422 post-listing events. Given our concerns about non-normality in returns and volume, the table presents a variety of statistics. The columns labeled "Before" and "After" present the means of variables in the periods before and after U.S. listing. Asterisks indicate whether the variable is significantly abnormal based on the non-parametric rank test of Corrado (1989). The columns labeled "Wtest" present a Wilcoxon non-parametric test of whether "Before" versus "After" sub-samples are significantly different. The columns labeled "T-test" present a standard parametric test of whether the "Before" versus "After" sub-samples are significantly different. Both the W-test and T-test statistics evaluate whether the "Before" period reaction is larger than the "After" period reaction.

Table 3 indicates statistically significantly greater return volatility and volume reactions to earnings shocks in the post-listing period. These heightened responses are particularly strong for volume, which typically doubles its size after U.S. listing. For example, the abnormal volume on the announcement day (as a percentage of the mean volume in the pre-event period) is 0.37 percent higher before a U.S. listing and 0.62 percent higher after a U.S. listing. This is statistically significant by both the Wilcoxon W-test and standard T-test. The differences in absolute abnormal returns are less dramatic. On the announcement day in the pre-listing period, we observe a 2.43 percent higher abnormal return, yet, in the post-listing period, it is only a 2.22 percent higher abnormal return. These are significant statistically by the $\mathrm{W}$-test but not by the Ttest. Skewness is evident in a few cases where the Wilcoxon and T-test statistics have different

\footnotetext{
24 This yields a few situations where newly-rich countries (such as Taiwan and Korea) are categorized with poorer countries that presumably have a poorer information environment.
} 
sign. ${ }^{25}$ It is interesting that the abnormal returns are significantly higher in the post-listing period on the days around the earnings announcement (days $-2,+1$ and +2 ). At the same time, the most prominent abnormal trading volume increases in the post-listing period occur on day +1 , but not in the pre-announcement window.

We also break the event study analysis into a variety of sub-samples. Table 4 reports abnormal absolute returns and abnormal trading volume in a window of three days, -1 through +1 , around the earnings announcement and compares those in the pre-listing and post-listing periods. Results are reported by emerging/developed market category, by region (Asia, Europe and the Americas), by listing type (Rule 144a, OTC and Exchange listing), by year of listing and according to the number of analysts following the stocks. The most striking result is that firms from developed, rather than emerging, economies show statistically significant increases in return volatility and trading volume after U.S. listing. The cumulative absolute abnormal return over the event period actually decreases from 3.37 percent before listing to 3.35 percent after listing, a statistically insignificant difference, for emerging-market firms. The cumulative absolute abnormal returns for developed market firms increases from 2.51 percent to 3.41 percent, a statistically significant increase at the 1 percent level. The cumulative abnormal trading volume increase after listing is statistically significant for both emerging and developed market firms and are of similar magnitudes.

This finding on return volatility and trading volume for developed-market firms is somewhat surprising given our hypotheses that firms from less-developed markets are likely to experience the most dramatic change in information environment upon U.S. listing. Sub-samples based on geographic area and degree of economic development confirm this, indicating that the

\footnotetext{
${ }^{25}$ Consider, for example, results for absolute abnormal returns at day 0 . The mean declines from 0.0243 to 0.0222 yielding a positive (though insignificant) T-test. The Wilcoxon statistic, however, is strongly negative, suggesting the presence of some large positive outliers in the "After" period.
} 
changes in return volatility and trading volume around earnings announcements are most pronounced for "Developed Europe." The cumulative absolute abnormal return increases from 2.17 percent before listing to 3.14 percent after listing (W-test of -4.59) and cumulative abnormal trading volume increases from 3.73 percent to 4.48 percent (W-test of -4.30 ). Interestingly, there is no significant change for Canada, suggesting that other national characteristics (such as the degree of difference between local and U.S. disclosure environments) beyond mere developed country status are relevant. Equally interesting is the case of Latin America ("Emerging America") for which there is a large (though statistically insignificant) decline in cumulative absolute abnormal return from 5.71 percent before listing to 3.57 percent after listing associated with a large increase in cumulative abnormal trading volume.

Table 4 also breaks the sample by listing type into Rule 144a, OTC, and exchange listings. The largest number of events is for OTC listings (658 pre-listing events and 703 postlisting events) and the smallest is for 144a (219 pre-listing events and 262 post-listing events). Surprisingly, the largest changes in event period volatility and volume are observed for over-thecounter listings, followed by $144 \mathrm{a}$ placements. The increase in cumulative absolute abnormal returns is from 2.51 percent to 3.22 percent for $144 \mathrm{a}$ listings and from 2.82 percent to 3.60 percent for OTC listings, statistically significant in both cases. The increase in cumulative abnormal trading volume is from 3.55 percent to 4.41 percent for $144 \mathrm{a}$ listings and from 3.50 percent to 4.74 percent for OTC listings, again both statistically significant differences. There is no significant change in either volatility or volume for exchange listings. In brief, the change in event study reaction is greatest for lower-level listings. These findings again appear to contradict our hypotheses that exchange listings would be associated with the largest change in return and volume because they demand greater disclosure. Table 1 shows that developed country firms tend to select OTC or exchange listings. Thus, the differences in event study results across listing 
type are likely mirroring the same effects we find in comparing developed country and emerging market results. We explore these types of interactions in the next subsection.

Figures 1 and 2 show the abnormal trading volume and volatility reactions for different subsets of firms by days around the earnings announcements before and after listing. In some cases, the cumulative effects are spread uniformly within the window of days -2 to +2 , such as that for developed-market firms and the increase in absolute abnormal returns (top of Figure 1). The volume reaction (bottom of Figure 1), however, shows that the cumulative volume increase after listing for developed-market firms is concentrated on days +1 and +2 . A similar result holds for the 144a and OTC listings in Figure 2. The increase in cumulative absolute abnormal returns after listing occurs uniformly over the five days in the window, but that for the cumulative abnormal trading volume is skewed towards days +1 and +2 .

Table 4 also indicates that the significant changes in event-period volatility and volume reactions are clustered in the final three years of our sample (1997 to 1999). Because the pace of international cross-listings has advanced, it is not surprising that the largest number of observations for the abnormal returns and abnormal trading volume after listing occurs during that sub-period. The relationship between the size of the return reaction and the number of analysts is complex and non-linear. The largest increase in cumulative absolute abnormal returns occurs for firms that have 5 to 25 analysts covering their stocks, which again is associated with the subgroups with most observations. Volume effects are weaker, however. In subsequent tests, we examine the significance of the change in the number of analysts after U.S. cross listing and the explanatory power of the change in the number of analysts in cross sectional regressions.

To sum up the evidence thus far, it appears that a U.S. listing alters substantially the information environment in a significant way: earnings shocks have a substantially greater impact on home-country return volatility and trading volume once the stock is cross-listed in the 
U.S. Do we infer that the precision and quality of the prior information has diminished such that there is more noise and more residual uncertainty incorporated into prices after listing? Do we associate the higher abnormal volume around earnings after listing with an increase in private information asymmetry or "disagreement" due to more information and more information processing? It is curious that this effect is greatest for those situations (firms from developed countries or firms that do not submit to high exchange listing standards) where we expected the change in information environment to be relatively modest. Interestingly, the developed country pattern relates primarily to European firms and excludes Canada.

\subsection{Cross-sectional regressions}

Table 5 summarizes some of the key explanatory variables used in the cross-sectional regressions. It is evident that there are often large changes comparing the pre-listing and postlisting periods. In particular, the number of analysts following a firm and the dispersion of analyst forecasts increase significantly after listing. The change in the number of analysts is greater for firms from developed countries and for firms that list as a 144a or OTC. This mirrors our earlier finding that the post listing increase in return volatility and volume around earnings is typically largest for developed country firms and those that list as 144a and OTC. Furthermore, the increase in forecast dispersion after U.S. listing is greatest for developed country firms, again suggesting that U.S. listing leads to particularly large increases in information asymmetry or "disagreement" in trading of developed country firms. The size of earnings surprises appears to increase dramatically after U.S. listing, although the changes are not statistically significant.

Table 6 presents estimates of cross-sectional regressions to explain cumulative absolute abnormal returns. Slope dummy terms are used to distinguish the pre-listing versus post-listing associations. Panel A of the table presents three preliminary specifications to further test the dependence of cumulative absolute abnormal returns on geography and degree of development 
of the home country. Panel B presents the main specifications (listed as 4 through 11) which include the firm-specific and country-level characteristics variables detailed previously. White heteroscedasticity-consistent t-statistics are reported along with adjusted R-squared.

Across all specifications, the association between absolute returns and the post listing dummy variable is typically positive, as is suggested by Tables 3 and 4 . The simple specification (model 1) shows a statistically significant increase of 0.839 percent across all firms (t-statistic of 5.30). After controlling for the post listing change in return volatility, geographic dummies indicate that prelisting return volatility around earnings announcements is larger for Emerging America (that is, Latin America) and smaller for Developed Europe. Note that the benchmark associated with the constant is defined by the Canadian sample of cross-listing firms. The coefficient on the Emerging America post listing slope dummy term is the only one that is significant and is negative and larger than the benchmark increase $(-2.25$ percent, $t$-statistic of 2.55 versus constant of 1.10 percent, t-statistic of 2.35 ). This indicates that the return volatility around earnings announcements decreases upon cross listing for Latin American firms. Though not significant, the slope dummy term is also negative for Emerging European $(-0.20$ percent) and Middle Eastern/African firms (-0.54 percent). Overall, this finding is contrary to our first hypothesis that the change in volatility reaction associated with the increased disclosure should be greatest for developing-country companies.

One possible explanation for the larger volatility increase around earnings announcements for developed firms is that the magnitude of the information release (earnings surprise) may be greater and other factors that relate to the event (number of analysts, dispersion of analyst forecasts) are different. Table 5 indicates that this is so. However, the traditional control variables from the accounting literature (the scale of the earnings surprise, the number of analysts following the firm, and the dispersion of earnings forecasts) are not significant in 
explaining return volatility around earnings announcements nor how it changes after cross listing in the U.S. In the Panel B of Table 6, various specifications (e.g. Models 7 through 11) show that the magnitude of the earnings shock is positive but small, the dispersion of analyst forecasts is also positive but small, and the number of analysts is negative and, at best, only marginally significant. Following Hayn (1995), we allow for an asymmetric impact of the earnings shock to volatility from positive and negative surprises ("positive shock" in table) and this coefficient is positive but not significant. The key result in the table is that the volatility increase is robust to the inclusion of these control variables.

After controlling for other factors, it appears that developed country listings and 144a listings are still associated with lower return volatility prior to U.S. listing. Moreover, the positive slopes on "Developed Post" and "144a Post" confirm our earlier finding that the increase in volatility is highest for firms from developed markets and those that use listings with only incremental disclosure requirements. It is interesting that both slope dummy variables are significant only in the full specification (Model 11) which implies important interactions with the control and country-level variables and listing type dummies. The strong positive slope coefficient on accounting standards variable indicates that higher return volatility around earnings announcements is associated with firms from countries with higher quality accounting environments. The slope coefficient on accounting standards when interacting with the postlisting dummy is negative and marginally significant at the 10 percent level. Taken together, these results suggest that the increase in volatility reactions to earnings is greater after crosslisting for all firms, on average, but the increase upon listing is greater for those firms from developed market countries with poorer accounting systems. The primary examples are firms from countries like Belgium, Denmark, Germany, Italy, Japan, the Netherlands, and Spain. 
There are large, negative coefficients on the "Positive Shock Post" slope dummy. This finding indicates that the return volatility reaction to negative earnings surprises becomes stronger than the return volatility reaction to positive earnings announcements in the post-listing period. Put another way, the sensitivity of the market to the sign of an earnings surprise is heightened after listing in the U.S. This suggests another dimension of the change in information environment that occurs upon cross listing in the U.S.

Table 7 presents cross-sectional results to explain abnormal trading volume in a format similar to Table 6. Across the two panels, there is only weak evidence that abnormal trading volume around earnings releases is more prominent after cross listing. Overall, the cumulative abnormal trading volume increases by 0.47 percent from an average prelisting volume reaction of 3.95 percent. There is no evidence that patterns in trading volume or post listing changes in trading volume relate to geographic classification or level of economic development. In the second panel, there is very strong evidence of a positive association between abnormal trading volume and the contemporaneous abnormal return volatility, as indicated by the strong positive slopes on "Absolute Return". This suggests that listing in the U.S. generates more information, more analysis, and therefore more information asymmetry or "disagreement" among traders. Though the absolute return typically rises after U.S. listing, the coefficient on the corresponding slope dummy is insignificant, suggesting that this association does not change upon cross listing.

The second panel of Table 7 indicates a strong positive relationship between abnormal trading volume and the number of analysts covering the firm. The coefficients on "Analysts Post" are significantly negative and of similar scale, suggesting that this positive relationship is neutralized after the firm lists in the U.S. Put another way, the impact of "disagreement" that is proportional to the number of analysts disappears once a firm cross-lists in the U.S. This occurs even though, as indicated in Table 5, the number of analysts increases after U.S. listing, 
particularly for the developed country firms and listings within only incremental disclosure requirements (144a or OTC). Cross listing in the U.S. induces information production and trading activity that cannot be captured by a simple linear relationship to analyst coverage.

\section{Alternative Interpretations of the Evidence}

In Section 2.3, we proposed two key hypotheses that derive from the accounting and finance literature on capital market reactions to public announcements, such as for annual earnings, and from the literature on international cross-listings. Our special focus was on the increased disclosure that firms face when they list their shares on U.S. markets. We first offered that the absolute volatility reaction to earnings announcements should diminish after firms list in the U.S. due to the higher quality and precision of the pre-disclosure prior information and the lower costs of information acquisition we would expect in the U.S. market environment. We also proposed that this decreased volatility reaction would be greatest for firms that come from lessdeveloped economies, those with weaker accounting standards, and those that pursue an exchange listing because these firms would experience the most dramatic increase in disclosure associated with the listing event. In Section 4 we found that the absolute abnormal return reactions to earnings announcements actually increased after U.S. listings. Moreover, this increase was robust even after controlling for variables associated with the magnitude of the information event, such as the earnings surprise (including an asymmetric effect), the number of analysts following the stock and the dispersions in their earnings forecasts. Most surprisingly, we found that this volatility increase was greatest for those firms from developed markets and those that face only incremental disclosure requirements by means of Rule 144a private placement and OTC listings. The weakness of home-country accounting standards for those cross-listed firms explains little of the increase in volatility reactions to earnings. 
We also offered a second hypothesis that implied that abnormal trading volume reactions around earnings announcements are positively associated with the dispersion of beliefs and asymmetry of private information among investors. So, if we observe higher (lower) abnormal trading volume reactions around earnings following a U.S. listing, this outcome is associated with greater (lesser) information asymmetry or dispersion of beliefs among investors. Further, we proposed that this change (in whichever direction) following listing should be more dramatic for those firms from less-developed markets, those with weaker accounting standards, and those that pursue full exchange listings requiring the largest increase in disclosure requirements. Our findings in Section 4 on the change in volume reactions are weaker than that on the change in volatility reactions. Overall, the volume reactions are larger following U.S. listing, which implies greater dispersion of beliefs and greater information asymmetry among investors, but it is primarily associated with developed-market firms and those with Rule 144a private placement and OTC listings.

There are a number of possible explanations for these surprising findings. We explore several that are inspired by new research in the literature in international accounting, finance, and legal systems. First, we begin with a number of robustness tests that we performed.

\subsection{Some Robustness Tests}

We explored a number of alternative specifications for our tests. First, we computed larger and smaller windows for the cumulative absolute abnormal returns and cumulative abnormal trading volume. We also investigated some nonlinear specifications involving multiple interactions (e.g. emerging markets and accounting standards), and particularly in regards to the country-level variables (e.g. accounting standards) and those associated with analyst following. We found that the most dramatic increase in absolute abnormal returns and abnormal trading volume occurred for firms from countries with intermediate accounting standards (with index 
values below 70 and above 60). This result was further concentrated in those firms from developed markets. Table 8 provides some evidence.

Clustering of particularly "hot" or volatile industries in developed countries with relatively low accounting standards might explain our finding of particularly large changes in earnings responses after U.S. listing. Appendix A describes the industrial composition of our sample by country. We have a large number of industrial firms (144 out of 427). Most of those firms are concentrated in Canada, Hong Kong, India, Taiwan, and the U.K. Consumer sector firms, which include many segments (e.g. food and beverage, electronics, household products, luxury goods, media and retailing), have the second largest contingent (97) and they are concentrated in the U.K. While the small number of firms within each country does not permit formal tests, it does not appear that there are any obvious differences in the industry composition of the sample across countries or regions. Further investigation of these issues is clearly warranted.

\subsection{Earnings Management and Investor Protection}

Earnings management is the act of obfuscating financial reports made to external stakeholders with the intent of obtaining some private gain. There has been evidence of earnings management by managers in overstating earnings prior to seasoned equity offerings (Teoh, Welch and Wong, 1998) and when approaching potential violations of their debt covenants with outside creditors (Sweeney, 1994). A number of papers have provided evidence of extensive earnings management in firms around the world (Leuz, Nanda and Wysocki, 2001; Bhattacharya, Daouk and Welker, 2001). Leuz et al., in particular, suggest that the extent of earnings management is strongly negatively related to the scope of legal protection in the home market because strong investor protection leads to less "diversion" and rent-seeking activities by insiders. 
This diversion hypothesis and Leuz et al.'s supportive findings suggest that firms that choose to list their shares in the U.S. where there is a tradition of strong legal protection of minority investors will have less latitude in earnings management. The diversion hypothesis is one possible explanation for the unexpected result of higher volatility reactions around earnings announcements following U.S. listings. While the quality and precision of prior information is greater with a U.S. listing, the quality of the financial reports are greater and the overall information content of the public announcement is greater. While we do try to control for dispersion of analyst forecasts and earnings surprise, it could be that the sensitivity of return volatility and trading volume to earnings news is simply greater in the new regime. Ideally, to get at this issue, we should examine whether there is greater smoothing of earnings, less frequent reporting of loss avoidance, less frequent use of accounting accruals and other similar actions after firms cross-list their shares in the U.S.

\subsection{Synchroneity of Stock Price Movements and Economic Development}

Stock prices have been shown to move together more in low-income economies than in high-income economies (Morck, Yeung and Yu, 2000). These authors have conjectured that the degree to which a country protects private property rights affects both the extent to which information is capitalized into stock prices and the sort of information that is capitalized. Specifically, they suggest that firm-specific information is much more likely to be capitalized in countries like the U.S. and Canada than in emerging economies like China and Indonesia. In those markets, poor property rights make informed risk arbitrage in their markets unattractive and stock prices are cross-sectionally more synchronous.

One reason we observe an unexpected increase in the volatility reactions around earnings announcements for firms that list their shares in the U.S. is that firm-specific return variation increases overall. With greater protection of property rights, risk arbitrageurs now find it worth 
their while to incorporate this information into prices. This finding is not necessarily consistent with our finding that firms from emerging markets are less likely than developed market firms to experience a significant increase in volatility and volume reactions upon listing. However, it would be useful to decompose the source of the cumulative absolute abnormal returns into components due to market-wide and firm-specific factors. In our current approach, we use a simple market model to estimate parameters in the pre-event period to compute residuals in the event period, but more general factor models may be worth exploring. It would also be useful to examine whether firm-specific variation increases following a U.S. listing.

The strength of property rights and investor protection laws are critical elements of this and the preceding explanation. In Table 8, we compute simple univariate tests of post-listing changes in cumulative absolute abnormal returns and cumulative abnormal trading volume according to classifications of legal tradition (English common law, French civil law, Scandinavian and German law) following LaPorta et al. (1998). Surprisingly, the most dramatic increase in volatility reactions following listing occurs for those firms from developed, Englishcommon-law and French-civil-law markets. The largest changes in abnormal trading volume are concentrated in the developed, English-common-law, Scandinavian-law and German-law firms. These results represent at least indirect evidence that legal tradition and systems might matter.

\subsection{Changing Composition of Ownership}

While the significantly higher volatility reaction to earnings announcement following a U.S. listing is more challenging result to explain than the higher abnormal volume, we also offer some possible explanations for the greater dispersion of beliefs or asymmetry of private information that is associated with higher volume. Institutional investors own a substantial 
fraction of the shares of internationally cross-listed stocks and especially ADRs. ${ }^{26}$ Utama and Cready (1997) have shown that ownership structure, as indicated by the percentage of outstanding shares held by institutional investors, is positively associated with trading volume reactions around earnings announcement dates. They associate this institutional participation with cross-investor variation in the precision of private information.

The greater dispersion of beliefs or information asymmetry may also stem from the much more geographically diverse investor base that is likely to arise from U.S. listings. There have been a number of studies that show that foreign investors have an informational disadvantage and these have been used to explain phenomena associated with cross-border equity and bond flows, the home bias puzzle and even international financial contagion. ${ }^{27}$ More recent studies, in contrast, suggest that foreign institutional investors have superior information because of access to international expertise and talent and considerable local resources (Grinblatt and Kelohaju, 2000; Seasholes, 2000, Choe, Kho and Stulz, 2000). Seasholes, in particular, shows that foreign investors buy (sell) ahead of good (bad) earnings announcements in Taiwan while local investors do the opposite. Whichever way the asymmetry lies, there is strong evidence that it exists. A useful extension of the current experiment is to study how the composition of the ownership base of these cross-listing firms changes among institutional/retail and foreign/local investors and whether this is related to the abnormal volatility and volume reactions around earnings.

\subsection{Disclosure Requirements and Signaling}

A number of studies have suggested that firms choose to list their shares on U.S. markets to signal their "quality" relative to their peers (Cantale, 1998, Moel, 1998, Fuerst, 1999, Huddart, Hughes and Brunnermeier, 1999). Using rational expectations models to examine how public

\footnotetext{
${ }^{26}$ See evidence in Citibank Report (July 2001) by Michael Chafkin on "U.S. Investment in Non-U.S. Equities" http://wwss.citissb.com/adr/www/adr_info/chaf.pdf.
} 
disclosure requirements affect listing decisions by rent-seeking corporate insiders and allocation decisions by liquidity traders seeking lowest trading costs, they establish conditions under which exchanges competing for global order flow engage in a 'race for the top' in disclosure standards. Further, when markets differ in their disclosure requirements for listed firms, the strictness of those requirements enable managers of highly profitable firms to credibly convey their private information regarding their firms' future prospects.

We found little evidence to support our hypotheses of diminished abnormal volatility and volume reaction around earnings for those firms that 'reached for the top' in reconciling with U.S. GAAP through exchange listings and those firms from developing countries with poor accounting standards. However, we did find evidence that volatility and volume reactions were heightened following U.S. listings for developed market firms that pursued Rule 144a private placements and OTC listings. This contrary evidence could be consistent with the complement of the "signaling hypothesis." Potential investors would have expected such developed market firms to choose exchange listings because of the relative small leap to reconciliation with U.S. GAAP. To the extent that they choose an alternative course that requires only incremental disclosure investors perceive this as a "bad signal." As a result, the magnitude of the update in beliefs given the content of the earnings announcement and the dispersion of those beliefs or asymmetry of private information surrounding the announcement is substantially greater. There is only limited empirical evidence on Rule 144a listings, but it is generally consistent with this interpretation of a "bad" signal. For example, Foerster and Karolyi (2000) find that Rule 144a private placements by firms from markets with relatively strong accounting standards significantly underperform various market benchmarks. Clearly, it would be useful to reconcile the evidence on returns

\footnotetext{
${ }^{27}$ See French and Poterba (1991), Cooper and Kaplanis (1995), Tesar and Werner (1995), Brennan and Cao (1997) and Kang and Stulz (1997).
} 
performance around listings and global equity offerings and in the post-listing period with our analysis of capital market reactions around earnings announcements.

\section{Conclusions}

We present empirical evidence that absolute abnormal returns and abnormal trading volume around earnings announcements by non-U.S. companies are economically and statistically larger if they choose to list their shares on U.S. markets. Our sample includes 2,695 earnings announcements for 427 non-U.S. companies from 44 emerging and developed countries. These findings are surprising, given that the increased disclosure standards and requirements these firms face by listing in the U.S. should have created a richer information environment with higher quality (more precise) prior information, lower information acquisition costs, and possibly lower disagreement or information asymmetry among investors. We further show that the increase in absolute abnormal returns and trading volume is concentrated in those firms from more developed countries and those firms that pursue U.S. listings by means of Rule 144a private placements and OTC listings, which require only incremental disclosure relative to their home markets.

The results are robust to a number of specifications. We control for the magnitude of the earnings surprise (using earnings forecasts by analysts), the increase in the number of analysts following the stocks, and even the dispersion in the analysts. The absolute abnormal returns and abnormal trading volume are cumulated over different length windows around the earnings announcements. The results are not an artifact of U.S. listings or earnings announcements in a particular year or years or of firms from a particular region, sector or industry.

We explore several possible interpretations of these findings. One possibility is that the U.S. listing significantly alters the composition of the ownership mix among 
institutional/individual and local/foreign investors, which creates substantially greater dispersion in the prior private information or interpretations of the earnings information. It could also be the case that corporate insiders and controlling shareholders have less scope for earnings management with a U.S. listing and the greater capital market reactions around earnings simply reflect the greater information content of the announcements. A related hypothesis focuses on the greater incentives for risk arbitrageurs to garner more firm-specific information about stocks once they list in the U.S. and seek to incorporate this information into prices. The greater volatility and volume reactions to earnings are thus due to lower synchroneity of stock price movements that occurs in developed markets like the U.S. with strong legal protection for public shareholders. Finally, the fact that the increased volatility and volume reactions to earnings stems primarily from developed market firms that pursue Rule 144a private placement and OTC listings that do not require increased disclosure may arise from investors' negative perception of this listing choice.

We recognize that these interpretations, though supported to some extent by our findings, remain conjectures. We invite alternative explanations and further empirical investigations of this issue. With our evidence to this point, however, it is difficult to support the case that these non-U.S. firms (and the investors of the firms) committing to increased levels of disclosure through U.S. listings gain economically and statistically significant benefits. 


\section{References}

Abarbanell, Jeffery S., William N. Lanen and Robert E. Verrecchia, 1995, Analysts' Forecasts As Proxies For Investor Beliefs In Empirical Research, Journal of Accounting and Economics 20, 31-60.

Admati, Anat R., and Paul Pfleiderer, 2000, Forcing Firms to Talk: Financial Disclosure and Externalities, Review of Financial Studies 13, 479-520.

Alexander, Gordon J., Cheol S. Eun and S. Janakiramanan, 1987, Asset Pricing And Dual Listing On Foreign Capital Markets: A Note, Journal of Finance 42, 151-158.

Alexander, Gordon J., Cheol S. Eun and S. Janakiramanan, 1988, International Listings And Stock Returns: Some Empirical Evidence, Journal of Financial and Quantitative Analysis 23, 135-152.

Alford, Andrew W. and Jonathan D. Jones, 1998, Financial Reporting And Information Asymmetry: An Empirical Analysis Of The SEC's Information-Supplying Exemption For Foreign Companies, Journal of Corporate Finance 4, 373-398.

Alford, Andrew, Jones, Jennifer, Leftwich, Richard, and Mark Zmijewski, 1993, The relative informativeness of accounting disclosures in different countries, Journal of Accounting Research 31, 183-229.

Amir, Eli, Trevor S. Harris and Elizabeth K. Venuti, 1993, A Comparison Of The ValueRelevance Of U.S. Versus Non-U.S. GAAP Accounting Measures Using Form 20-F Reconciliations," Journal of Accounting Research 31, 230-275.

Atiase, Rowland K., and Linda Smith Bamber, 1994, Trading volume reactions to annual accounting earnings announcements: the incremental role of predisclosure information asymmetry, Journal of Accounting and Economics 17, 309-29.

Bailey, Warren, Chung, Y. Peter, and Jun-koo Kang, 1999, Foreign ownership restrictions and equity price premiums: What drives the demand for cross-border investments?, Journal of Financial and Quantitative Analysis 34, 489-512.

Baker, W. Kent, John R. Nofsinger, Daniel P. Weaver, 2001, International Cross-listing and Visibility, Journal of Financial and Quantitative Analysis, forthcoming.

Bamber, Linda Smith and Youngsoon Susan Cheon, 1995, Differential Price And Volume Reactions To Accounting Earnings Announcements, Accounting Review 70, 417-441.

Barron, Orie E., and Oamela S. Stuerke, 1998, Dispersion in analyst' earnings forecasts as a measure of uncertainty, Journal of Accounting, Auditing, and Finance 13, 235-270.

Barry, Christopher B. and Stephen J. Brown, 1984, Differential Information And The Small Firm Effect, Journal of Financial Economics 13, 283-294. 
Barry, Christopher B. and Stephen J. Brown, 1985, Differential Information And Security Market Equilibrium, Journal of Financial and Quantitative Analysis 20, 407-422.

Barth, Mary E., Greg Clinch and Toshi Shibano, 1999, International Accounting Harmonization And Global Equity Markets, Journal of Accounting and Economics 26, 201-235.

Bessembinder, Hendrik, Chan, Kalok, and Paul J. Sequin, 1996, An empirical examination of information, differences of opinion, and trading activity, Journal of Financial Economics 40, 105-134.

Bhattacharya, Utpal, Hazem Daouk, and Michael Welker, 2001, The World Price of Earnings Management, unpublished Indiana University working paper.

Bhushan, Ravi, 1989, Firm Characteristics And Analyst Following, Journal of Accounting and Economics 11, 255-274.

Black, Fischer, 1974, International Capital Market Equilibrium With Investment Barriers, Journal of Financial Economics 1, 337-352.

Blume, Lawrence, David Easley and Maureen O'Hara, 1994, Market Statistics And Technical Analysis: The Role Of Volume, Journal of Finance 49, 153-181.

Brennan, Michael J., and H. Henry Cao, 1997, International portfolio investment flows, Journal of Finance 52, 1851-80.

Brown, Stephen J., and Jerold B. Warner, 1985, Using daily stock returns: the case of event studies, Journal of Financial Economics 14, 3-31.

Cantale, Salvatore, 1996, The choice of a foreign market as a signal, unpublished Tulane University working paper

Campbell, John Y., Sanford J. Grossman and Jiang Wang, 1993, Trading Volume And Serial Correlation In Stock Returns, Quarterly Journal of Economics 108, 905-939.

Chan, Kam C. and Gim S. Seow, 1996, The Association Between Stock Returns And Foreign GAAP Earnings Versus Earnings Adjusted To U.S. GAAP, Journal of Accounting and Economics 21, 139-158.

Chang, James, Khanna, Tarun, and Krishna Palepu, 2000, Analyst activity around the world, unpublished Harvard Business School working paper.

Choe, Hyuk, Kho, Bong-Chan, and René M. Stulz, 2000, Do domestic investors have more information about individual stocks than foreign investors?, Ohio State University working paper 2000-21. 
Chung, Kee H., 2000, Marketing stocks by brokerage firms: The role of financial analysts, Financial Management 29, 35-54.

Coffee, John C. Jr., 1999, The future as history: the prospects for global convergence in corporate governance and its implications, Northwestern University Law Review 93, 641-708.

Cooper, Ian and Evi Kaplanis, 1995, Home Bias In Equity Portfolios And The Cost Of Capital For Multinational Firms, Journal of Applied Corporate Finance 8, 95-102.

Corrado, Charles J., 1989, A Non-Parametric Test for abnormal security-price performance in event studies, Journal of Financial Economics 23, 385-95.

Corrado, Charles J., and Terry L. Zivney, 1992, The specification and power of the sign test in event study hypothesis tests using daily stock returns, Journal of Financial and Quantitative Analysis, 465-478.

Decker, William E., 1994, The Attractions of the U.S. Securities Markets to Foreign Issuers and the Alternative Methods of Accessing the U.S. Markets: From the Issuer's Perspective, Fordham International Law Journal 17, S10-S24.

Diamond, Douglas W. and Robert E. Verrecchia, 1991, Disclosure, Liquidity, And The Cost Of Capital, Journal of Finance 46, 1325-1360.

Doidge, Craig, 2001, Do laws matter for corporate ownership and control? Evidence from emerging markets firms that list in the U.S., unpublished Ohio State University working paper.

Doidge, Craig, G. Andrew Karolyi, Rene M. Stulz, 2001, Why are Foreign Firms Listed in the U.S. Worth More?, unpublished Ohio State University and NBER working paper.

Errunza, Vihang and Etienne Losq, 1985, International Asset Pricing Under Mild Segmentation: Theory And Test, Journal of Finance 40, 105-124.

Fanto, James A., and Roberta S. Karmel, 1997, A Report on the Attitudes of Foreign Companies Regarding a U.S. Listing, Stanford Journal of Law, Business, and Finance 3, 46-82.

Foerster, Stephen, and G. Andrew Karolyi, 1993, International Listings and Stock Price Reactions: The Case of Canada and the U.S., Journal of International Business Studies 24, 763-784.

Foerster, Stephen, and G. Andrew Karolyi, 1998, Multimarket Trading and Liquidity: A Transactions Data Analysis of Canada-U.S. Interlistings, Journal of International Financial Markets, Institutions and Money 8, 393-412. 
Foerster, Stephen, and G. Andrew Karolyi, 1999, The Effects of Market Segmentation and Investor Recognition on Asset Prices: Evidence from Foreign Stocks Listing in the U.S., Journal of Finance 54, 981-1013.

Foerster, Stephen, and G. Andrew Karolyi, 2000, "The Long Run Performance of Global Equity Offerings," Journal of Financial and Quantitative Analysis 35, 499-528.

Fox, Merritt B., 1998, The Political Economy of Statutory Reach: U.S. Disclosure Rules in a Globalizing Market for Securities, Michigan Law Review 97, 696-822.

French, Kenneth R., and James M. Poterba, 1991, Investor diversification and international equity markets, American Economic Review 81, 222-26.

Frost, Carol A. and Grace Pownall, 1994, A Comparison Of The Stock Price Response To Earnings Disclosures In The United States And The United Kingdom, Contemporary Accounting Research 11, 59-83.

Fuerst, Oren, 1998, A Theoretical Analysis of the Investor Protection Regulations Argument for Global Listing of Stocks, unpublished Yale University working paper.

Grinblatt, Mark, and Matti Kelohaju, 2000, The investment behavior and performance of various investor types: a study of Finland's unique data set, Journal of Financial Economics 55, 43-67.

Grundy, Bruce D. and Maureen McNichols, 1989, Trade And Revelation Of Information Through Prices And Direct Disclosure, Review of Financial Studies 2, 495-526.

Harris, Mary S. and Karl A. Muller III, 1999, The Market Valuation Of IAS Versus US-GAAP Accounting Measures Using Form 20-F Reconciliations, Journal of Accounting and Economics 26, 285-312.

Harris, Milton and Artur Raviv, 1993, Differences Of Opinion Make A Horse Race, Review of Financial Studies 6, 473-506.

Hayn, Carla, 1995, The Information Content of Losses, Journal of Accounting and Economics 20, 125-153.

He, Hua, and Jiang Wang, 1995, Differential Information and Dynamic Behavior of Stock Trading Volume, Review of Financial Studies 8, 919-972.

Healy, Paul M., A. Hutton and Krishna G. Palepu, 1999, Stock Performance and Intermediation Changes Surrounding Sustained Increases in Disclosure Conteporary Accounting Research 16, 485-520.

Healy, Paul M. and Krishna G. Palepu, 1993, The Effect Of Firms' Financial Disclosure Strategies On Stock Prices," Accounting Horizons 7, 1-11. 
Healy, Paul M. and Krishna G. Palepu, 2001, Information Asymmetry, Corporate Disclosure, And The Capital Markets: A Review Of The Emirical Disclosure Literature, Journal of Accounting and Economics 31, 405-440.

Huddart, Steven, John S. Hughes and Markus Brunnermeier, 1999, Disclosure Requirements And Stock Exchange Listing Choice In An International Context, Journal of Accounting and Economics 26, 237-269.

Kandel, Eugene, and Neil D. Pearson, 1995, Differential interpretation of public signals and trade in speculative markets, Journal of Political Economy 103, 831-872.

Kang, Jun-Koo and Rene M. Stulz, 1997, Why Is There A Home Bias? An Analysis Of Foreign Portfolio Equity Ownership In Japan, Journal of Financial Economics 46, 3-28.

Karamanou, Irene, and Jana Smith Raedy, 2000, Financial Analysts' Forecast Revisions as Evidence of the Usefulness of Form 20F Reconciliations and Disclosures, unpublished Penn State University working paper.

Karolyi, G. Andrew, 1998, Why Do Companies List Their Shares Abroad? A Survey of the Evidence and its Managerial Implications, Volume 7, Number 1, Salomon Brothers Monograph Series, New York University.

Karolyi, G. Andrew, 2001, DaimlerChrysler AG, The First Truly Global Share, unpublished Ohio State University working paper.

Kato, Kiyoshi, Scott Linn and James Schallheim, 1991, Are There Arbitrage Opportunities In The Market For American Depository Receipts?, Journal of International Financial Markets, Institutions and Money 1, 73-89.

Kim, Jeong-Bon, Krinsky, Itzhak, and Jason Lee, 1997, Institutional holding and trading volume reactions to quarterly earnings announcements, Journal of Accounting, Auditing, and Finance 12, 1-14.

Kim, Oliver, and Robert E. Verrecchia, 1991a, Trading volume and price reactions to public announcements, Journal of Accounting Research 29, 302-321.

Kim, Oliver, and Robert E. Verrecchia, 1991b, Market reaction to anticipated announcements, Journal of Financial Economics 30, 273-310.

Kim, Oliver, and Robert E. Verrecchia, 1994, Market liquidity and volume around earnings announcements, Journal of Accounting and Economics 17, 41-67.

Kim, O. and R. E. Verrecchia, 2001, The Relation Among Disclosure, Returns, And Trading Volume Information, Accounting Review 76, 633-654.

La Porta, Rafael, Lopez-de-Silanes, Florencio, Shleifer, Andre, and Robert W. Vishny, 1998, Law and Finance, Journal of Political Economy 106, 1113-1155. 
Lang, Mark H. and Russell J. Lundholm, 1996, Corporate Disclosure Policy And Analyst Behavior, Accounting Review 71, 467-492.

Leuz, Christian, 2001, IAS versus US GAAP: A New Market Based Comparison, unpublished University of Pennsylvania working paper.

Leuz, Christian, Dhananjay Nanda and Peter D. Wysocki, 2001, Investor Protection and Earnings Management: An International Comparison, unpublished University of Pennsylvania working paper.

Leuz, Christian and Robert E. Verrecchia, 2000, The Economic Consequences Of Increased Disclosure, Journal of Accounting Research 38, 91-124.

Lins, Karl, Strickland, Deon, and Marc Zenner, 2000, Do non U.S. firms issue equity in U.S. stock exchanges to relax capital constraints?, unpublished University of North Carolina working paper.

Maynes, Elizabeth., and John Rumsey, 1993, Conducting event studies with thinly traded stocks, Journal of Banking and Finance 17, 145-157.

Merton, Robert C., 1987, A simple model of capital market equilibrium with incomplete information, Journal of Finance 42, 483-510.

Miller, Darius P., 1999, The market reaction to international cross-listings: Evidence from Depositary Receipts, Journal of Financial Economics 51, 103-123

Miller, Darius P. and Matthew R. Morey, 1996, The Intraday Pricing Behavior Of International Dually Listed Securities, Journal of International Financial Markets, Institutions and Money 6, 79-89.

Moel, Alberto, 1998, The Role of Information Disclosure on Stock Market Listing Decisions, unpublished Harvard University working paper.

Morck, Randall, Bernard Yeung and Wayne Yu, 2000, The Information Content Of Stock Markets: Why Do Emerging Markets Have Synchronous Stock Price Movements?, Journal of Financial Economics 58, 215-260.

Myers, Stewart C. and Nicholas S. Majluf, 1984, Corporate Financing And Investment Decisions When Firms Have Information That Investors Do Not Have, Journal of Financial Economics 13, 187-221.

Nenova, Tatiana, 2001, The Value of Corporate Votes and Control Benefits: A Cross-country Analysis, unpublished Harvard University working paper.

O’Hara, Maureen, 1997, Market Microstructure Theory, Blackwell Publishers, Malden, MA. 
Park, Jinwoo and Amir Tavakkol, 1994, Are ADRs A Dollar Translation Of Their Underling Securities? The Case Of Japanese ADRs, Journal of International Financial Markets, Institutions and Money 4, 77-87.

Rader, M. Elizabeth, 1994, Accounting Issues in Cross-Border Securities Offerings, Fordham International Law Journal 17, S129-S139.

Rajan, Raghuram and Henri Servaes, 1997, Analyst Following Of Initial Public Offerings, Journal of Finance 52, 507-529.

Rees, Lynn and Pieter Elgers, 1997, The Market's Valuation Of Nonreported Accounting Measures: Retrospective Reconciliations Of Non-U.S. And U.S. GAAP, Journal of Accounting Research 35, 115-127.

Reese, W., and M. Weisbach, 2001, Protection of minority shareholder interests, cross-listings in the United States, and subsequent equity offerings, unpublished NBER working paper.

Ruder, David S., 1996, "Reconciling U.S. Disclosure Policy with International Accounting and Disclosure Standards" Northwestern Journal of International Law and Business 17, 1-14.

Salva, Carolina, 2000, Foreign Listings, Corporate Governance and Equity Valuations, unpublished Cornell University Department of Economics working paper.

Seasholes, Mark, 2000, Smart foreign traders in emerging markets, unpublished Harvard Business School working paper.

Stapleton, R. C. and M. G. Subrahmanyam, 1977, Market Imperfections, Capital Market Equilibrium And Corporation Finance, Journal of Finance 32, 307-319.

Stulz, René M., 1981, A Model Of International Asset Pricing, Journal of Financial Economics, 9, 383-406.

Stulz, René M., 1999, Globalization, corporate finance, and the cost of capital, Journal of Applied Corporate Finance 12, 8-25.

Sweeney, Amy Patricia, 1994, Debt-Covenant Violations And Managers' Accounting Responses, Journal of Accounting and Economics 17, 281-308.

Teoh, Siew Hong, Ivo Welch and T. J. Wong, 1998, Earnings Management And The Long-Run Market Performance Of Initial Public Offerings, Journal of Finance 53, 1935-1974.

Tesar, Linda L. and Ingrid M. Werner, 1995, Home Bias And High Turnover, Journal of International Money and Finance 14, 467-493.

Utama, Siddharta and William M. Cready, 1997, Institutional Ownership, Differential Predisclosure Precision And Trading Volume At Announcement Dates, Journal of Accounting and Economics 24, 129-150. 
Verrecchia, Robert E., 2001, Essays On Disclosure, Journal of Accounting and Economics 32, 98-180.

Wang, Jiang, 1994, A model of competitive stock trading volume, Journal of Political Economy 102,127-168. 
Table 1. Depositary Receipt Programs by Type. Four different levels of American Depositary Receipt programs are available with various conditions on trading, registration requirements with the SEC (Securities Act of 1933) and reporting requirements (Securities and Exchange Act of 1934). More details are available from Bank of New York (www.bankofny.com), JP Morgan (www.adr.com) and Citibank (wwss.citissb.com/adr/www).

\begin{tabular}{|c|c|c|c|c|c|}
\hline \multirow[t]{2}{*}{ Item } & \multicolumn{2}{|c|}{ No Capital Raising } & \multicolumn{3}{|c|}{ Capital Raising with New Issue } \\
\hline & Level-I & $\underline{\text { Level-II }}$ & Level-III & Rule 144A & Global Offering \\
\hline Description & Unlisted & $\begin{array}{l}\text { Listed on Major } \\
\text { U.S. Exchange }\end{array}$ & $\begin{array}{l}\text { Offered and } \\
\text { Listed on } \\
\text { Major U.S. } \\
\text { Exchange }\end{array}$ & $\begin{array}{l}\text { Private U.S. } \\
\text { Placement to } \\
\text { Qualified } \\
\text { Institutional } \\
\text { Buyers (QIBs) }\end{array}$ & $\begin{array}{l}\text { Offer of in two } \\
\text { or more markets; } \\
\text { but not home } \\
\text { market of issuer }\end{array}$ \\
\hline $\begin{array}{l}\text { Trading } \\
\text { Location }\end{array}$ & $\begin{array}{l}\text { OTC Pink Sheet } \\
\text { trading }\end{array}$ & $\begin{array}{l}\text { NYSE, AMEX or } \\
\text { Nasdaq }\end{array}$ & $\begin{array}{l}\text { NYSE, AMEX } \\
\text { or Nasdaq }\end{array}$ & $\begin{array}{l}\text { U.S. Private } \\
\text { Placement } \\
\text { Market using } \\
\text { PORTAL }\end{array}$ & $\begin{array}{l}\text { U.S. and } \\
\text { Non-U.S. } \\
\text { Exchanges }\end{array}$ \\
\hline SEC Registration & $\begin{array}{l}\text { Registration } \\
\text { Statement Form } \\
\text { F-6 }\end{array}$ & $\begin{array}{l}\text { Registration } \\
\text { Statement Form } \\
\text { F-6 }\end{array}$ & $\begin{array}{l}\text { Form F-1 and } \\
\text { F-6 for initial } \\
\text { public offering }\end{array}$ & None & $\begin{array}{l}\text { Private } \\
\text { placement, } \\
\text { as Rule144A } \\
\text { or, new issue, } \\
\text { as Level III }\end{array}$ \\
\hline $\begin{array}{l}\text { U.S. Reporting } \\
\text { Required }\end{array}$ & $\begin{array}{l}\text { Exemption under } \\
\text { Rule 12g3-2(b) }\end{array}$ & $\begin{array}{l}\text { Form } 20-F \text { filed } \\
\text { annually }\end{array}$ & $\begin{array}{l}\text { Form } 20-\mathrm{F} \\
\text { filed annually; } \\
\text { short forms } \\
\text { F-2 and F-3 } \\
\text { used only for } \\
\text { subsequent } \\
\text { offerings }\end{array}$ & $\begin{array}{l}\text { Exemption } \\
\text { under Rule } \\
12 \mathrm{~g} 3-2(\mathrm{~b})\end{array}$ & $\begin{array}{l}\text { Private } \\
\text { placement, } \\
\text { as Rule144A } \\
\text { or, new issue, } \\
\text { as Level III }\end{array}$ \\
\hline $\begin{array}{l}\text { GAAP } \\
\text { Requirement }\end{array}$ & $\begin{array}{l}\text { No GAAP } \\
\text { reconciliation } \\
\text { required }\end{array}$ & $\begin{array}{l}\text { Only Partial } \\
\text { reconciliation for } \\
\text { financials }\end{array}$ & $\begin{array}{l}\text { Full GAAP } \\
\text { reconciliation } \\
\text { for financials }\end{array}$ & $\begin{array}{l}\text { No GAAP } \\
\text { reconciliation } \\
\text { required }\end{array}$ & $\begin{array}{l}\text { Private } \\
\text { placement, } \\
\text { as Rule144A } \\
\text { or, new issue, } \\
\text { as Level III }\end{array}$ \\
\hline
\end{tabular}


Table 2. Descriptive Statistics. This table describes the number of non-U.S. firms listing in the U.S. in our sample (classified by country of origin and by type of listing) and the number of earning announcement events available before and after listing. "Accounting" is an indicator of the information environment in the local market and is measured with the index presented in La Porta et al (1998).

\begin{tabular}{|c|c|c|c|c|c|c|c|c|c|}
\hline & Code & $\begin{array}{l}\text { Accounting } \\
\text { Standards }\end{array}$ & $\begin{array}{l}\text { Number } \\
\text { of Firms }\end{array}$ & $\begin{array}{l}\text { Events } \\
\text { before } \\
\text { Listing }\end{array}$ & $\begin{array}{c}\text { Events } \\
\text { after } \\
\text { Listing }\end{array}$ & & $\begin{array}{l}\text { Number } \\
\text { of Firms }\end{array}$ & $\begin{array}{l}\text { Events } \\
\text { before } \\
\text { Listing }\end{array}$ & $\begin{array}{c}\text { Events } \\
\text { after } \\
\text { Listing }\end{array}$ \\
\hline Country: & & & & & & Listing/Exchange: & & & \\
\hline Argentina & AR & 45 & 5 & 8 & 20 & $144 \mathrm{~A}$ & 85 & 219 & 262 \\
\hline Australia & $\mathrm{AU}$ & 75 & 18 & 44 & 69 & OTC & 207 & 658 & 703 \\
\hline Germany & BD & 62 & 15 & 64 & 47 & GDRs & 10 & 19 & 28 \\
\hline Belgium & BG & 61 & 3 & 12 & 13 & AMEX & 2 & 9 & 8 \\
\hline Brazil & BR & 54 & 23 & 58 & 62 & NAS & 26 & 68 & 85 \\
\hline Colombia & $\mathrm{CB}$ & 50 & 3 & 4 & 8 & NYSE & 97 & 300 & 336 \\
\hline China & $\mathrm{CH}$ & - & 3 & 6 & 5 & Total & 427 & 1273 & 1422 \\
\hline Chile & CL & 52 & 10 & 21 & 38 & & & & \\
\hline Canada & $\mathrm{CN}$ & 74 & 42 & 129 & 146 & Emerging Markets & & & \\
\hline Czech Rep & $\mathrm{CZ}$ & - & 1 & 1 & 2 & $144 \mathrm{~A}$ & 74 & 176 & 223 \\
\hline Denmark & DK & 62 & 1 & 3 & 6 & OTC & 43 & 93 & 116 \\
\hline Spain & $\mathrm{ES}$ & 64 & 5 & 19 & 19 & GDRs & 10 & 19 & 28 \\
\hline Finland & $\mathrm{FN}$ & 77 & 3 & 10 & 10 & AMEX & 0 & 0 & 0 \\
\hline France & FR & 69 & 13 & 56 & 57 & NAS & 4 & 14 & 13 \\
\hline Greece & GR & 55 & 2 & 6 & 3 & NYSE & 25 & 62 & 78 \\
\hline Hong Kong & HK & 69 & 45 & 162 & 165 & Total Emerging & 156 & 364 & 458 \\
\hline Hungary & $\mathrm{HN}$ & - & 4 & 7 & 7 & & & & \\
\hline Indonesia & ID & - & 1 & 2 & 1 & Developed Market & ets: & & \\
\hline India & IN & 57 & 28 & 46 & 86 & $144 \mathrm{~A}$ & 11 & 43 & 39 \\
\hline Ireland & IR & - & 5 & 18 & 19 & OTC & 164 & 565 & 587 \\
\hline Israel & IS & - & 2 & 3 & 5 & GDRs & 0 & 0 & 0 \\
\hline Italy & IT & 62 & 4 & 16 & 12 & AMEX & 2 & 9 & 8 \\
\hline Japan & $\mathrm{JP}$ & 65 & 20 & 79 & 77 & NAS & 22 & 54 & 72 \\
\hline Korea & KO & 62 & 12 & 45 & 47 & NYSE & 72 & 238 & 258 \\
\hline Luxembourg & LX & 61 & 1 & 4 & 3 & Total Developed & 271 & 909 & 964 \\
\hline Mexico & MX & 60 & 10 & 24 & 22 & & & & \\
\hline Malaysia & MY & 76 & 4 & 9 & 13 & Total & 427 & 1273 & 1422 \\
\hline Netherlands & NL & 64 & 10 & 28 & 42 & & & & \\
\hline Norway & NW & 74 & 5 & 18 & 24 & & & & \\
\hline Austria & $\mathrm{OE}$ & 54 & 7 & 19 & 16 & & & & \\
\hline Peru & $\mathrm{PE}$ & 38 & 2 & 2 & 6 & & & & \\
\hline Philippines & $\mathrm{PH}$ & 65 & 4 & 5 & 19 & & & & \\
\hline Poland & $\mathrm{PO}$ & - & 2 & 4 & 2 & & & & \\
\hline Portugal & PT & 36 & 1 & 2 & 3 & & & & \\
\hline Russia & $\mathrm{RS}$ & - & 2 & 2 & 2 & & & & \\
\hline South Africa & SA & 70 & 13 & 49 & 40 & & & & \\
\hline Sweden & SD & 83 & 4 & 5 & 9 & & & & \\
\hline Singapore & SG & 78 & 13 & 31 & 41 & & & & \\
\hline Slovakia & SJ & - & 1 & 1 & 1 & & & & \\
\hline Switzerland & SW & 68 & 7 & 25 & 30 & & & & \\
\hline Taiwan & TA & 65 & 19 & 53 & 61 & & & & \\
\hline Thailand & $\mathrm{TH}$ & 64 & 2 & 2 & 2 & & & & \\
\hline Turkey & TK & 51 & 3 & 6 & 6 & & & & \\
\hline UK & UK & 78 & 49 & 165 & 156 & & & & \\
\hline Total & & & 427 & 1273 & 1422 & & & & \\
\hline
\end{tabular}


Table 3. Absolute Abnormal Returns and Abnormal Trading Volume around Earnings Announcements before and Cross-Listing. We report absolute abnormal returns and abnormal volumes around earning announcements both before and after cross-listing in the U.S. Abnormal returns are residuals from the one-factor OLS market model. Abnormal volumes are obtained by the difference of volume and the mean volume computed over the estimation window $(-200,-11)$ divided by the mean volume. Similar results are obtained if abnormal volume is adjusted by the median instead. Corrado's (1989) nonparametric rank test is computed to test for significance. ** and $*$ indicate $5 \%$ and $10 \%$ significance respectively. We also test whether return volatility and abnormal volume are significantly different before and after cross-listing. Wilcoxon two-sample nonparametric tests ("W-test") and ordinary T-tests ("T-test") are computed and reported below. Median two-sample nonparametric tests are also computed (not reported) to check for robustness.

\begin{tabular}{|c|c|c|c|c|c|c|c|c|}
\hline \multirow[b]{2}{*}{ Day } & \multicolumn{4}{|c|}{ Absolute Abnormal Return } & \multicolumn{4}{|c|}{ Abnormal Trading Volume } \\
\hline & Before & After & W-test & T-test & Before & After & $\mathrm{W}$-test & T-test \\
\hline-20 & 0.0148 & 0.0162 & -1.54 & -1.62 & 0.0950 & 0.0595 & -0.30 & 0.66 \\
\hline-19 & $0.0144 * *$ & 0.0161 & -2.72 & -2.00 & 0.0773 & 0.0832 & -1.95 & -0.09 \\
\hline-18 & 0.0164 & 0.0158 & -0.04 & 0.67 & 0.1123 & 0.0467 & -0.47 & 1.14 \\
\hline-17 & 0.0153 & 0.0161 & -0.10 & -0.92 & 0.0336 & 0.0057 & -1.59 & 0.51 \\
\hline-16 & $0.0142 * *$ & 0.0164 & -2.94 & -2.75 & 0.1228 & 0.0278 & 0.28 & 1.57 \\
\hline-15 & 0.0145 & 0.0167 & -2.49 & -2.96 & 0.0968 & 0.1382 & -1.97 & -0.62 \\
\hline-14 & 0.0148 & 0.0163 & -2.17 & -2.01 & 0.1998 & 0.0733 & -0.10 & 1.65 \\
\hline-13 & 0.0148 & 0.0152 & -1.33 & -0.53 & 0.0085 & 0.0260 & -0.44 & -0.37 \\
\hline-12 & 0.0140 & $0.0166 *$ & -3.77 & -3.54 & 0.0441 & 0.1079 & -1.51 & -1.02 \\
\hline-11 & 0.0157 & 0.0159 & -1.13 & -0.19 & 0.1161 & 0.1911 & -1.39 & -0.55 \\
\hline-10 & 0.0153 & 0.0159 & -0.52 & -0.84 & 0.1124 & 0.1769 & -0.17 & -0.69 \\
\hline-9 & $0.0160 *$ & 0.0155 & 0.33 & 0.67 & 0.2697 & 0.1117 & -0.74 & 1.69 \\
\hline-8 & 0.0161 & 0.0156 & 0.19 & 0.58 & 0.1476 & 0.1889 & -2.53 & -0.41 \\
\hline-7 & 0.0152 & 0.0164 & -3.32 & -1.35 & 0.1301 & 0.2552 & -3.18 & -0.86 \\
\hline-6 & 0.0151 & 0.0167 & -2.75 & -1.98 & 0.1478 & 0.2131 & -3.54 & -0.74 \\
\hline-5 & 0.0162 & 0.0172 & -1.88 & -1.23 & 0.1816 & $0.3002 *$ & -2.78 & -0.88 \\
\hline-4 & 0.0163 & 0.0165 & -1.83 & -0.22 & 0.5443 & $0.3590 *$ & -2.34 & 0.46 \\
\hline-3 & 0.0160 & 0.0170 & -1.76 & -1.12 & $0.2896 * *$ & 0.2451 & -0.10 & 0.38 \\
\hline-2 & $0.0166 * *$ & $0.0184 * *$ & -2.51 & -2.01 & $0.2657 *$ & $0.3439 * *$ & -2.28 & -0.50 \\
\hline-1 & $0.0172 * *$ & $0.0183 * *$ & -2.00 & -1.21 & $0.2337 * *$ & $0.4079 * *$ & -2.96 & -1.31 \\
\hline 0 & 0.0243 & $0.0222 * *$ & -4.97 & 0.32 & $0.3715 * *$ & $0.6248 * *$ & -3.95 & -1.70 \\
\hline 1 & $0.0164 *$ & $0.0187 * *$ & -3.37 & -2.57 & $0.2979 * *$ & $0.6528 * *$ & -3.24 & -2.89 \\
\hline 2 & $0.0157 *$ & $0.0176 *$ & -2.19 & -2.38 & $0.2693 * *$ & $0.5436 * *$ & -3.53 & -1.82 \\
\hline 3 & 0.0143 & 0.0157 & -1.61 & -1.93 & 0.1703 & $0.3517 *$ & -3.26 & -1.78 \\
\hline 4 & 0.0150 & 0.0167 & -2.22 & -2.23 & 0.1677 & 0.1641 & -1.86 & 0.05 \\
\hline 5 & 0.0166 & 0.0162 & -1.14 & 0.42 & 0.1743 & $0.2594 *$ & -1.95 & -1.01 \\
\hline 6 & 0.0160 & 0.0159 & 0.16 & 0.14 & 0.4131 & 0.2080 & -0.85 & 1.58 \\
\hline 7 & 0.0146 & 0.0158 & -1.72 & -1.48 & 0.1658 & 0.3557 & -1.35 & -1.31 \\
\hline 8 & 0.0148 & 0.0160 & -1.70 & -1.63 & 0.1658 & 0.2768 & -2.46 & -0.85 \\
\hline 9 & 0.0157 & 0.0156 & -0.87 & 0.12 & $0.2069 *$ & 0.3106 & -0.42 & -1.01 \\
\hline 10 & 0.0155 & 0.0164 & -0.53 & -0.68 & $0.2142 *$ & 0.1732 & 0.31 & 0.55 \\
\hline
\end{tabular}


Table 4. Univariate tests on cumulative absolute abnormal returns and cumulative abnormal trading volume. Averages of cumulative abnormal returns and trading volumes in a 3-day window $(-1,+1)$ around the earnings event are averaged for the period before versus after U.S. listing. "N" indicates the number of earnings events in the category. Wilcoxon two-sample nonparametric tests ("W-test") indicate whether the difference across time periods is significant. ** and * indicate significance at the $1 \%$ and $5 \%$ levels respectively. A negative test statistic indicates that the variable is typically larger in the post listing period.

\begin{tabular}{|c|c|c|c|c|c|c|c|c|c|c|}
\hline \multirow{3}{*}{$\frac{\text { Categories }}{\text { All }}$} & \multicolumn{5}{|c|}{ Cumulative Absolute Abnormal Returns $(-1,+1)$} & \multicolumn{5}{|c|}{ Cumulative Abnormal Trading Volume $(-1,+1)$} \\
\hline & \multicolumn{2}{|c|}{ Before Listing } & \multicolumn{2}{|c|}{ After Listing } & \multirow{2}{*}{$\frac{\mathrm{W} \text {-test }}{-5.09^{* *}}$} & \multicolumn{2}{|c|}{ Before Listing } & \multicolumn{2}{|c|}{ After Listing } & \multirow{2}{*}{$\begin{array}{l}\text { W-test } \\
-4.03^{* *}\end{array}$} \\
\hline & 1271 & 0.02756 & 1421 & 0.03383 & & 1056 & 3.73101 & 1324 & 4.50813 & \\
\hline Emerging & 362 & 0.03375 & 457 & 0.03335 & -1.52 & 252 & 3.30885 & 402 & 4.57799 & $-2.14 *$ \\
\hline Developed & 909 & 0.02509 & 964 & 0.03406 & $-4.92 * *$ & 804 & 3.86333 & 922 & 4.47768 & $-4.06 * *$ \\
\hline \multicolumn{11}{|l|}{ By Region } \\
\hline Emerging Asia & 168 & 0.02428 & 234 & 0.03347 & $-2.19 *$ & 127 & 3.71284 & 227 & 4.31060 & -1.83 \\
\hline Developed Asia & 316 & 0.02625 & 352 & 0.03483 & $-2.19 *$ & 297 & 3.59221 & 352 & 4.16463 & $-2.43 *$ \\
\hline Emerging Europe & 26 & 0.03101 & 22 & 0.03925 & 0.62 & 24 & 3.51806 & 20 & 3.89157 & 0.72 \\
\hline Developed Europe & 464 & 0.02169 & 466 & 0.03140 & $-4.59 * *$ & 380 & 3.73734 & 429 & 4.48502 & $-4.30 * *$ \\
\hline Middle East, Africa & 52 & 0.02663 & 45 & 0.02890 & 1.53 & 45 & 3.03114 & 45 & 3.85763 & $2.33 *$ \\
\hline Emerging America & 92 & 0.05705 & 134 & 0.03567 & 1.60 & 32 & 2.42093 & 88 & 6.38782 & 0.37 \\
\hline Canada & 129 & 0.03445 & 146 & 0.04071 & -0.80 & 127 & 4.87435 & 141 & 5.23688 & 0.27 \\
\hline \multicolumn{11}{|l|}{ By Listing Type } \\
\hline 144 & 219 & 0.02509 & 262 & 0.03221 & $-2.89 * *$ & 173 & 3.54560 & 250 & 4.41311 & $-2.96 * *$ \\
\hline OTC listing & 657 & 0.02815 & 703 & 0.03600 & $-4.20 * *$ & 558 & 3.50284 & 648 & 4.74271 & $-3.56 * *$ \\
\hline Exchange listed & 377 & 0.02800 & 429 & 0.03157 & -1.71 & 317 & 4.25485 & 401 & 4.27664 & -0.50 \\
\hline \multicolumn{11}{|l|}{ By Year } \\
\hline 1989 to 1992 & 496 & 0.02410 & 81 & 0.01868 & -1.45 & 398 & 3.01935 & 73 & 3.38514 & 0.70 \\
\hline 1993 to 1994 & 402 & 0.02999 & 185 & 0.02892 & 0.34 & 335 & 4.06527 & 173 & 3.95750 & 1.11 \\
\hline 1995 to 1996 & 282 & 0.02895 & 413 & 0.02758 & 1.26 & 245 & 3.98741 & 390 & 4.33735 & -1.09 \\
\hline 1997 to 1999 & 91 & 0.03133 & 742 & 0.04019 & $-3.00 * *$ & 78 & 5.12134 & 688 & 4.86255 & $2.68 * *$ \\
\hline \multicolumn{11}{|l|}{ By Analyst Coverage } \\
\hline Up to 4 analysts & 401 & 0.03262 & 192 & 0.03301 & 0.89 & 317 & 3.58683 & 176 & 3.52800 & -0.09 \\
\hline 5 to 12 analysts & 522 & 0.02541 & 475 & 0.03558 & $3.44 * *$ & 437 & 3.53709 & 446 & 4.76891 & $-2.00 *$ \\
\hline 13 to 25 analysts & 296 & 0.02486 & 503 & 0.03425 & $-3.69 * *$ & 252 & 4.03292 & 458 & 4.79887 & -0.63 \\
\hline 26 or more analysts & 52 & 0.02535 & 251 & 0.03031 & $1.98 *$ & 50 & 4.81836 & 244 & 4.19271 & 0.54 \\
\hline
\end{tabular}


Table 5. Descriptions and summary statistics for key explanatory variables. This table presents pre-listing and post-listing averages for several characteristics used as explanatory variables in subsequent regressions. Wilcoxon two-sample nonparametric statistics test ("Wtest") whether the number of analysts forecasting earnings for a firm, the size of the earnings surprise, the market value of the firm, and the predisclosure information asymmetry proxy are significantly different before and after an international cross-listing.

\begin{tabular}{|c|c|c|c|c|c|c|}
\hline Variable & Description & Вy Туре & $\begin{array}{l}\text { Before } \\
\text { Listing }\end{array}$ & $\begin{array}{r}\text { After } \\
\text { Listing }\end{array}$ & $\begin{array}{r}\text { Difference } \\
\text { (W-test) }\end{array}$ & \\
\hline \multirow{9}{*}{ Analysts } & \multirow{9}{*}{$\begin{array}{l}\text { Number of analysts who give } \\
\text { earnings forecasts to } / \mathrm{B} / \mathrm{E} / \mathrm{S} \\
\text { for a given firm during the } \\
\text { current fiscal year. Proxy for } \\
\text { the amount of research } \\
\text { devoted to a firm. }\end{array}$} & All & 9.45 & 15.56 & 6.11 & $* *$ \\
\hline & & Emerging & 5.81 & 11.14 & 5.33 & $* *$ \\
\hline & & Developed & 10.90 & 17.65 & 6.75 & $* *$ \\
\hline & & Rule 144a & 5.51 & 11.79 & 6.28 & $* *$ \\
\hline & & OTC & 10.40 & 17.07 & 6.67 & $* *$ \\
\hline & & GDRs & 2.84 & 7.39 & 4.55 & $* *$ \\
\hline & & AMEX & 9.78 & 13.75 & 3.97 & \\
\hline & & NAS & 7.78 & 11.55 & 3.77 & $* *$ \\
\hline & & NYSE & 11.02 & 17.07 & 6.05 & $* *$ \\
\hline \multirow{3}{*}{$\begin{array}{l}\text { Earnings } \\
\text { Surprise }\end{array}$} & \multirow{3}{*}{$\begin{array}{l}\text { Absolute value of announced } \\
\text { earning minus latest available } \\
\text { mean of } \mathrm{I} / \mathrm{B} / \mathrm{E} / \mathrm{S} \text { forecasts, } \\
\text { divided by the absolute value } \\
\text { of the mean forecast }\end{array}$} & All & 2.11 & 3.92 & 1.81 & \\
\hline & & Emerging & 5.15 & 7.45 & 2.30 & \\
\hline & & Developed & 0.27 & 2.24 & 1.97 & \\
\hline \multirow{3}{*}{ Market Cap } & \multirow{3}{*}{$\begin{array}{l}\text { Market Capitalization in } \\
\text { millions of US dollars }\end{array}$} & All & 3,093 & 4,721 & 1,628 & $* *$ \\
\hline & & Emerging & 1,249 & 1.672 & 423 & \\
\hline & & Developed & 3.677 & 6.006 & 2,329 & $* *$ \\
\hline \multirow{3}{*}{ Dispersion } & \multirow{3}{*}{$\begin{array}{l}\text { Standard deviation of last } \\
\text { analysts' forecasts divided by } \\
\text { the absolute value of the mean } \\
\text { forecast. Proxy for } \\
\text { predisclosure information } \\
\text { asymmetry }\end{array}$} & All & 0.24 & 1.29 & 1.05 & $* *$ \\
\hline & & Emerging & 0.35 & 0.67 & 0.32 & \\
\hline & & Developed & 0.31 & 1.59 & 1.28 & $* *$ \\
\hline
\end{tabular}


Table 6. Cross-sectional regressions to explain cumulative absolute abnormal returns. This table reports cross-sectional regressions to explain the cumulative absolute abnormal return in a 3-day window $(-1,+1)$ around earnings events. Geographic, development, listing type, and post listing variables are dummy variables. Slope dummy variables indicated by "Post" suffix equal zero if the earnings event occurs before the U.S. listing. White heteroscedasticity consistent t-statistics are reported beneath each estimated coefficient. See Table 5 and the text for detailed descriptions of variables.

Panel A: By Region

\begin{tabular}{|c|c|c|c|}
\hline Variables & 1 & 2 & 3 \\
\hline Constant & $\begin{array}{r}0.02594 \\
(27.71)\end{array}$ & $\begin{array}{r}0.02886 \\
(11.22)\end{array}$ & $\begin{array}{r}0.02929 \\
(13.55)\end{array}$ \\
\hline Emerging Asia & & $\begin{array}{r}-0.00586 \\
(-1.80)\end{array}$ & \\
\hline Developed Asia & & $\begin{array}{r}-0.00093 \\
(-0.28)\end{array}$ & \\
\hline Emerging Europe & & $\begin{array}{r}-0.00163 \\
(-0.22)\end{array}$ & \\
\hline Developed Europe & & $\begin{array}{r}-0.00702 \\
(-2.45)\end{array}$ & \\
\hline Middle East, Africa & & $\begin{array}{r}-0.00540 \\
(-1.11)\end{array}$ & \\
\hline Emerging America & & $\begin{array}{r}0.01681 \\
(2.43)\end{array}$ & \\
\hline Developed & & & $\begin{array}{r}-0.00440 \\
(-1.84)\end{array}$ \\
\hline Post Listing Dummy & $\begin{array}{r}0.00839 \\
(5.30)\end{array}$ & $\begin{array}{r}0.01099 \\
(2.35)\end{array}$ & $\begin{array}{r}0.00398 \\
(1.39)\end{array}$ \\
\hline Emerging Asia Post & & $\begin{array}{r}0.00021 \\
(0.04)\end{array}$ & \\
\hline Developed Asia Post & & $\begin{array}{r}-0.00347 \\
(-0.56)\end{array}$ & \\
\hline Emerging Europe Post & & $\begin{array}{r}-0.00195 \\
(-0.14)\end{array}$ & \\
\hline Developed Europe Post & & $\begin{array}{r}-0.00073 \\
(-0.14)\end{array}$ & \\
\hline Middle East, Africa Post & & $\begin{array}{r}-0.00541 \\
(-0.75)\end{array}$ & \\
\hline Emerging America Post & & $\begin{array}{r}-0.02246 \\
(-2.55)\end{array}$ & \\
\hline Developed Post & & & $\begin{array}{r}0.00589 \\
(1.71)\end{array}$ \\
\hline Adjusted R-squared & 0.012 & 0.019 & 0.012 \\
\hline
\end{tabular}


Table 6. Cross-sectional regressions to explain cumulative absolute abnormal returns. (continued)

Panel B: By Attributes

\begin{tabular}{|c|c|c|c|c|c|c|c|c|}
\hline Variables & 4 & 5 & 6 & 7 & 8 & 9 & 10 & 11 \\
\hline Constant & $\begin{array}{r}0.02578 \\
(16.15)\end{array}$ & $\begin{array}{r}0.02610 \\
(27.37)\end{array}$ & $\begin{array}{r}0.02980 \\
(13.31)\end{array}$ & $\begin{array}{r}0.02598 \\
(15.24)\end{array}$ & $\begin{array}{r}0.02829 \\
(12.92)\end{array}$ & $\begin{array}{r}0.02623 \\
(10.80\end{array}$ & $\begin{array}{r}0.02620 \\
(15.18)\end{array}$ & $\begin{array}{r}0.03280 \\
(9.67)\end{array}$ \\
\hline Developed & & & $\begin{array}{r}-0.00482 \\
(-1.97)\end{array}$ & & $\begin{array}{r}-0.00376 \\
(-1.48)\end{array}$ & & & $\begin{array}{r}-0.00819 \\
(-2.40)\end{array}$ \\
\hline $144 \mathrm{~A}$ & $\begin{array}{r}-0.00202 \\
(-0.78)\end{array}$ & & & & & $\begin{array}{r}-0.00266 \\
(-0.96)\end{array}$ & & $\begin{array}{r}-0.00738 \\
(-2.19)\end{array}$ \\
\hline OTC & $\begin{array}{r}0.00087 \\
(0.41)\end{array}$ & & & & & $\begin{array}{r}0.00110 \\
(0.52)\end{array}$ & & $\begin{array}{r}0.00160 \\
(0.74)\end{array}$ \\
\hline Accounting $\left(\times 10^{2}\right)$ & & $\begin{array}{r}0.00006 \\
(1.98)\end{array}$ & $\begin{array}{r}0.00008 \\
(2.45)\end{array}$ & & & & $\begin{array}{r}0.00006 \\
(2.21)\end{array}$ & $\begin{array}{r}0.00008 \\
(2.57)\end{array}$ \\
\hline Dispersion & & & & $\begin{array}{r}0.00117 \\
(1.24)\end{array}$ & $\begin{array}{r}0.00117 \\
(1.26)\end{array}$ & $\begin{array}{r}0.00118 \\
(1.24)\end{array}$ & $\begin{array}{r}0.00117 \\
(1.25)\end{array}$ & $\begin{array}{r}0.00120 \\
(1.28)\end{array}$ \\
\hline Earning shock & & & & $\begin{array}{r}0.00011 \\
(0.08)\end{array}$ & $\begin{array}{r}0.00013 \\
(0.09)\end{array}$ & $\begin{array}{r}0.00004 \\
(0.03)\end{array}$ & $\begin{array}{r}0.00006 \\
(0.05)\end{array}$ & $\begin{array}{r}-0.00009 \\
(-0.06)\end{array}$ \\
\hline Positive shock & & & & $\begin{array}{r}0.00292 \\
(1.58)\end{array}$ & $\begin{array}{r}0.00283 \\
(1.54)\end{array}$ & $\begin{array}{r}0.00284 \\
\quad(1.53)\end{array}$ & $\begin{array}{r}0.00294 \\
(1.59)\end{array}$ & $\begin{array}{r}0.00249 \\
(1.35)\end{array}$ \\
\hline Analysts & & & & $\begin{array}{r}-0.00020 \\
(-1.57)\end{array}$ & $\begin{array}{r}-0.00011 \\
(-0.97)\end{array}$ & $\begin{array}{r}-0.00021 \\
(-1.81)\end{array}$ & $\begin{array}{r}-0.00018 \\
(-1.68)\end{array}$ & $\begin{array}{r}-0.00016 \\
(-1.34)\end{array}$ \\
\hline Post listing dummy & $\begin{array}{r}0.00609 \\
(2.52)\end{array}$ & $\begin{array}{r}0.00805 \\
(5.05)\end{array}$ & $\begin{array}{r}0.00306 \\
(1.06)\end{array}$ & $\begin{array}{r}0.01277 \\
(3.62)\end{array}$ & $\begin{array}{r}0.00881 \\
(2.44)\end{array}$ & $\begin{array}{r}0.01049 \\
(2.60)\end{array}$ & $\begin{array}{r}0.01200 \\
(3.36)\end{array}$ & $\begin{array}{r}0.00112 \\
(0.24)\end{array}$ \\
\hline Developed Post & & & $\begin{array}{r}0.00661 \\
(1.92)\end{array}$ & & $\begin{array}{r}0.007303 \\
(1.89)\end{array}$ & & & $\begin{array}{r}0.01180 \\
(2.67)\end{array}$ \\
\hline 144A Post & $\begin{array}{r}0.00405 \\
(1.02)\end{array}$ & & & & & $\begin{array}{r}0.00375 \\
(0.92)\end{array}$ & & $\begin{array}{r}0.01070 \\
(2.34)\end{array}$ \\
\hline OTC Post & $\begin{array}{r}0.00346 \\
(0.99)\end{array}$ & & & & & $\begin{array}{r}0.00357 \\
(1.00)\end{array}$ & & $\begin{array}{r}0.00303 \\
(0.85)\end{array}$ \\
\hline Accounting Post & & $\begin{array}{r}-0.00015 \\
(-1.64)\end{array}$ & $\begin{array}{r}-0.00017 \\
(-1.88)\end{array}$ & & & & $\begin{array}{r}-0.00015 \\
(-1.65)\end{array}$ & $\begin{array}{r}-0.00018 \\
(-1.94)\end{array}$ \\
\hline Dispersion Post & & & & $\begin{array}{r}0.00323 \\
(1.49)\end{array}$ & $\begin{array}{r}0.00333 \\
(1.53)\end{array}$ & $\begin{array}{r}0.00325 \\
\quad(1.50)\end{array}$ & $\begin{array}{r}0.00337 \\
(1.57)\end{array}$ & $\begin{array}{r}0.00346 \\
(1.62)\end{array}$ \\
\hline Earning shock Post & & & & $\begin{array}{r}-0.00023 \\
(-0.07)\end{array}$ & $\begin{array}{r}-8.5 \mathrm{E}-05 \\
(-0.02)\end{array}$ & $\begin{array}{r}-0.00013 \\
(-0.04)\end{array}$ & $\begin{array}{r}-2.9 \mathrm{E}-05 \\
(-0.01)\end{array}$ & $\begin{array}{r}0.00029 \\
(0.09)\end{array}$ \\
\hline Positive shock Post & & & & $\begin{array}{r}-0.00977 \\
(-3.42)\end{array}$ & $\begin{array}{r}-0.00994 \\
(-3.42)\end{array}$ & $\begin{array}{r}-0.00968 \\
(-3.38)\end{array}$ & $\begin{array}{r}-0.00981 \\
(-3.44)\end{array}$ & $\begin{array}{r}-0.00960 \\
(-3.32)\end{array}$ \\
\hline Analysts Post & & & & $\begin{array}{r}0.00001 \\
(0.09)\end{array}$ & $\begin{array}{r}-0.00009 \\
(-0.49)\end{array}$ & $\begin{array}{r}0.00003 \\
(0.15)\end{array}$ & $\begin{array}{r}0.00004 \\
(0.27)\end{array}$ & $\begin{array}{r}-0.00004 \\
(-0.20)\end{array}$ \\
\hline Adjusted RSQ & 0.011 & 0.012 & 0.013 & 0.020 & 0.020 & 0.020 & 0.020 & 0.023 \\
\hline
\end{tabular}


Table 7. Cross-sectional regressions to explain cumulative abnormal trading volume. This table reports cross-sectional regressions to explain cumulative abnormal trading volume in a 3-day window $(-1$, +1 ) around earnings events. Geographic, development, listing type, and post listing variables are dummy variables. Slope dummy variables indicated by "Post" suffix equal zero if the earnings event occurs before ADR introduction. White heteroscedasticity consistent t-statistics are reported beneath each estimated coefficient. See Table 4 and the text for detailed descriptions of variables.

Panel A: By Region

\begin{tabular}{|c|c|c|c|}
\hline Variables & 1 & 2 & 3 \\
\hline Constant & $\begin{array}{r}3.95004 \\
(24.41)\end{array}$ & $\begin{array}{r}4.65070 \\
(6.21)\end{array}$ & $\begin{array}{r}3.61057 \\
(11.48)\end{array}$ \\
\hline Emerging Asia & & $\begin{array}{r}-0.61008 \\
(-0.68)\end{array}$ & \\
\hline Developed Asia & & $\begin{array}{r}-0.82945 \\
(-1.03)\end{array}$ & \\
\hline Emerging Europe & & $\begin{array}{r}-0.75936 \\
(-0.68)\end{array}$ & \\
\hline Developed Europe & & $\begin{array}{r}-0.77945 \\
(-1.01)\end{array}$ & \\
\hline Middle East, Africa & & $\begin{array}{r}-1.59685 \\
(-1.63)\end{array}$ & \\
\hline Emerging America & & $\begin{array}{r}-1.02314 \\
-0.93\end{array}$ & \\
\hline Developed & & & $\begin{array}{r}0.42378 \\
(1.16)\end{array}$ \\
\hline Post Listing dummy & $\begin{array}{r}0.46750 \\
(2.06)\end{array}$ & $\begin{array}{r}0.52510 \\
(0.51)\end{array}$ & $\begin{array}{r}0.05080 \\
(0.12)\end{array}$ \\
\hline Emerging Asia Post & & $\begin{array}{r}-0.40079 \\
(-0.32)\end{array}$ & \\
\hline Developed Asia Post & & $\begin{array}{r}0.05642 \\
(0.05)\end{array}$ & \\
\hline Emerging Europe Post & & $\begin{array}{r}-0.55989 \\
(-0.36)\end{array}$ & \\
\hline Developed Europe Post & & $\begin{array}{r}0.26854 \\
(0.25)\end{array}$ & \\
\hline Middle East, Africa Post & & $\begin{array}{r}0.13372 \\
(0.11)\end{array}$ & \\
\hline Emerging America Post & & $\begin{array}{r}-1.65018 \\
(-1.24)\end{array}$ & \\
\hline Developed Post & & & $\begin{array}{r}0.61907 \\
(1.25)\end{array}$ \\
\hline Adjusted RSQ & 0.002 & 0.005 & 0.006 \\
\hline
\end{tabular}


Table 7. Cross-sectional regressions to explain cumulative abnormal trading volume. (continued).

Panel B: By Attributes

\begin{tabular}{|c|c|c|c|c|c|c|c|c|}
\hline Variables & 4 & 5 & 6 & 7 & 8 & 9 & 10 & 11 \\
\hline Constant & $\begin{array}{r}4.47601 \\
(11.61)\end{array}$ & $\begin{array}{r}3.95248 \\
(24.30)\end{array}$ & $\begin{array}{r}3.59792 \\
(10.99)\end{array}$ & $\begin{array}{r}2.70969 \\
(8.38)\end{array}$ & $\begin{array}{r}2.60637 \\
(6.32)\end{array}$ & $\begin{array}{r}3.19039 \\
(6.71)\end{array}$ & $\begin{array}{r}2.70869 \\
(8.34)\end{array}$ & $\begin{array}{r}2.67679 \\
(5.00)\end{array}$ \\
\hline Developed & & & $\begin{array}{r}0.43745 \\
(1.16)\end{array}$ & & $\begin{array}{r}0.16553 \\
(0.44)\end{array}$ & & & $\begin{array}{r}0.65331 \\
(1.54)\end{array}$ \\
\hline $144 \mathrm{~A}$ & $\begin{array}{r}-0.59971 \\
(-1.10)\end{array}$ & & & & & $\begin{array}{r}-0.29936 \\
(-0.56)\end{array}$ & & $\begin{array}{r}0.11512 \\
(0.21)\end{array}$ \\
\hline OTC & $\begin{array}{r}-0.78649 \\
(-1.85)\end{array}$ & & & & & $\begin{array}{r}-0.74181 \\
(-1.75)\end{array}$ & & $\begin{array}{r}-0.79254 \\
(-1.85)\end{array}$ \\
\hline Accounting $\left(\times 10^{2}\right)$ & & $\begin{array}{r}0.00002 \\
(0.20)\end{array}$ & $\begin{array}{r}-0.00002 \\
(-0.13)\end{array}$ & & & & $\begin{array}{r}-0.00001 \\
(-0.05)\end{array}$ & $\begin{array}{r}-0.00003 \\
(-0.30)\end{array}$ \\
\hline Absolute return & & & & $\begin{array}{r}30.1774 \\
(4.55)\end{array}$ & $\begin{array}{r}30.1255 \\
(4.55)\end{array}$ & $\begin{array}{r}30.0605 \\
(4.60)\end{array}$ & $\begin{array}{r}30.1815 \\
(4.55)\end{array}$ & $\begin{array}{r}30.0417 \\
(4.59)\end{array}$ \\
\hline Earning shock & & & & $\begin{array}{r}0.07551 \\
(0.58)\end{array}$ & $\begin{array}{r}0.07101 \\
(0.54)\end{array}$ & $\begin{array}{r}0.09214 \\
(0.66)\end{array}$ & $\begin{array}{r}0.07576 \\
(0.59)\end{array}$ & $\begin{array}{r}0.08340 \\
(0.59)\end{array}$ \\
\hline Positive shock & & & & $\begin{array}{r}-0.09992 \\
(-0.31)\end{array}$ & $\begin{array}{r}-0.10251 \\
(-0.32)\end{array}$ & $\begin{array}{r}-0.15135 \\
(-0.46)\end{array}$ & $\begin{array}{r}-0.10063 \\
(-0.32)\end{array}$ & $\begin{array}{r}-0.14541 \\
(-0.44)\end{array}$ \\
\hline Analysts & & & & $\begin{array}{r}0.04781 \\
(2.36)\end{array}$ & $\begin{array}{r}0.04536 \\
(2.21)\end{array}$ & $\begin{array}{r}0.04820 \\
(2.46)\end{array}$ & $\begin{array}{r}0.04786 \\
(2.36)\end{array}$ & $\begin{array}{r}0.04366 \\
(2.20)\end{array}$ \\
\hline Post listing dur & $\begin{array}{r}-0.09510 \\
(-0.19)\end{array}$ & $\begin{array}{r}0.46690 \\
(2.05)\end{array}$ & $\begin{array}{r}0.03588 \\
(0.08)\end{array}$ & $\begin{array}{r}0.29596 \\
(0.67)\end{array}$ & $\begin{array}{r}-0.08971 \\
(-0.16)\end{array}$ & $\begin{array}{r}-0.13383 \\
(-0.22)\end{array}$ & $\begin{array}{r}0.31193 \\
(0.71)\end{array}$ & $\begin{array}{r}-0.55374 \\
(-0.88)\end{array}$ \\
\hline Developed Post & & & $\begin{array}{r}0.63701 \\
(1.24)\end{array}$ & & $\begin{array}{r}0.95583 \\
(1.84)\end{array}$ & & & $\begin{array}{r}1.01541 \\
(1.89)\end{array}$ \\
\hline 144A Post & $\begin{array}{r}0.69824 \\
(0.92)\end{array}$ & & & & & $\begin{array}{r}0.26055 \\
(0.35)\end{array}$ & & $\begin{array}{r}0.74858 \\
(1.07)\end{array}$ \\
\hline OTC Post & $\begin{array}{r}0.82626 \\
(1.47)\end{array}$ & & & & & $\begin{array}{r}0.62539 \\
(1.14)\end{array}$ & & $\begin{array}{r}0.48774 \\
(0.87)\end{array}$ \\
\hline Accounting Post & & $\begin{array}{r}0.00002 \\
(0.01)\end{array}$ & $\begin{array}{r}-0.00004 \\
(-0.32)\end{array}$ & & & & $\begin{array}{r}0.00009 \\
(0.62)\end{array}$ & $\begin{array}{r}0.00002 \\
(0.15)\end{array}$ \\
\hline Absolute return Post & & & & $\begin{array}{r}10.0840 \\
(1.10)\end{array}$ & $\begin{array}{r}9.6766 \\
(1.06)\end{array}$ & $\begin{array}{r}10.2565 \\
(1.12)\end{array}$ & $\begin{array}{r}10.1711 \\
(1.10)\end{array}$ & $\begin{array}{r}9.71344 \\
(1.06)\end{array}$ \\
\hline Earning shock Post & & & & $\begin{array}{r}-0.36996 \\
(-1.30)\end{array}$ & $\begin{array}{r}-0.32679 \\
(-1.12)\end{array}$ & $\begin{array}{r}-0.38769 \\
(-1.33)\end{array}$ & $\begin{array}{r}-0.37064 \\
(-1.30)\end{array}$ & $\begin{array}{r}-0.32951 \\
(-1.12)\end{array}$ \\
\hline Positive shock Post & & & & $\begin{array}{r}0.42382 \\
(1.00)\end{array}$ & $\begin{array}{r}0.32428 \\
(0.77)\end{array}$ & $\begin{array}{r}0.47578 \\
(1.10)\end{array}$ & $\begin{array}{r}0.42526 \\
(1.00)\end{array}$ & $\begin{array}{r}0.33483 \\
(0.78)\end{array}$ \\
\hline Analysts Post & & & & $\begin{array}{r}-0.05574 \\
(-2.34)\end{array}$ & $\begin{array}{r}-0.06873 \\
(-2.76)\end{array}$ & $\begin{array}{r}-0.05555 \\
(-2.40)\end{array}$ & $\begin{array}{r}-0.05648 \\
(-2.36)\end{array}$ & $\begin{array}{r}-0.06661 \\
(-2.76)\end{array}$ \\
\hline Adjusted RSQ & 0.002 & 0.001 & 0.005 & 0.085 & 0.089 & 0.085 & 0.084 & 0.092 \\
\hline
\end{tabular}


Table 8. Robustness tests on cumulative absolute abnormal returns and cumulative abnormal trading volume. Averages of cumulative abnormal returns and trading volumes in a 3-day window $(-1,+1)$ around the earnings event are averaged for the period before versus after ADR listing. " $\mathrm{N}$ " indicates the number of earnings events in the category. Wilcoxon two-sample nonparametric tests ("W-test") indicate whether the difference across time periods is significant. ** and * indicate significance at the $1 \%$ and $5 \%$ levels respectively. A negative test statistic indicates that the variable is typically larger in the post listing period.

\begin{tabular}{|c|c|c|c|c|c|c|c|c|c|c|}
\hline \multirow[b]{3}{*}{ Category } & \multicolumn{5}{|c|}{$\begin{array}{l}\text { Cumulative Absolute Abnormal Return }(-1,+1) \\
\text { Before US }\end{array}$} & \multicolumn{5}{|c|}{$\begin{array}{l}\text { Cumulative Abnormal Trading Volume }(-1,+1) \\
\text { Before US }\end{array}$} \\
\hline & & Listing & fter US & S Listing & Difference & & Listing & After US & S Listing & Difference \\
\hline & $\mathrm{N}$ & Mean & $\mathrm{N}$ & Mean & W-test & $\mathrm{N}$ & Mean & $\mathrm{N}$ & Mean & W-test \\
\hline English law, developed & 549 & 0.02806 & 596 & 0.03742 & $-2.83 * *$ & 514 & 4.01228 & 564 & 4.64695 & $-2.27^{*}$ \\
\hline English law, emerging & 109 & 0.02718 & 146 & 0.02988 & -1.12 & 69 & 3.24789 & 139 & 4.20456 & -1.52 \\
\hline French law, developed & 133 & 0.01932 & 146 & 0.02578 & $-2.48 *$ & 98 & 3.72111 & 144 & 4.04925 & -1.24 \\
\hline French law, emerging & 135 & 0.04933 & 185 & 0.03454 & 1.33 & 74 & 2.80430 & 139 & 4.96940 & 1.04 \\
\hline German law, developed & 187 & 0.01992 & 170 & 0.02970 & $3.16^{* *}$ & 167 & 3.64239 & 169 & 4.33037 & $-3.13 * *$ \\
\hline German law, emerging & 98 & 0.02122 & 108 & 0.03372 & $-2.60 * *$ & 91 & 3.85286 & 108 & 4.48779 & $-2.68 * *$ \\
\hline Scandinavian law, developed & 36 & 0.02879 & 49 & 0.03350 & -0.70 & 25 & 2.83446 & 44 & 3.94645 & $-2.34^{*}$ \\
\hline Accounting standard $<60$, developed & 39 & 0.01733 & 38 & 0.03067 & 1.89 & 21 & 3.00470 & 19 & 4.41686 & 1.38 \\
\hline Accounting standard $<60$, emerging & 175 & 0.04436 & 253 & 0.03579 & 0.57 & 79 & 2.94170 & 198 & 5.39854 & -1.36 \\
\hline Accounting standard $>59,<70$, developed & 468 & 0.02233 & 471 & 0.03301 & $-4.18 * *$ & 407 & 3.72131 & 466 & 4.32807 & $-3.94 * *$ \\
\hline Accounting standard $>59,<70$, emerging & 129 & 0.02312 & 151 & 0.03228 & $-1.94 *$ & 121 & 3.60467 & 151 & 3.86208 & -1.26 \\
\hline Accounting standard $>69$, developed & 402 & 0.02905 & 455 & 0.03544 & $-2.08^{*}$ & 376 & 4.06503 & 437 & 4.63988 & -1.62 \\
\hline
\end{tabular}


Appendix A. Industrial Composition of Sample Firms. This table categorizes sample firms by industry group. "Commercial Industrial" includes aerospace, airlines, autos, chemicals, construction, electrical, engineering, office equipment, packaging, rubber, steel, services, technology, textile, and transportation. "Consumer" includes beverage, consumer electronics, cosmetics, drugs, food and tobacco, household products, hotel, luxury goods, media and entertainment, publishing, and retailing. "Natural resource" includes mining, oil and gas, paper and forestry.

\begin{tabular}{|c|c|c|c|c|c|c|c|c|c|}
\hline Country & Code & Total firms & $\begin{array}{c}\text { Banking, } \\
\text { Insurance, } \\
\text { Real } \\
\text { Estate } \\
\end{array}$ & $\begin{array}{c}\text { Commercial, } \\
\text { Industrial } \\
\end{array}$ & Consumer & $\begin{array}{c}\text { Multi sector, } \\
\text { other }\end{array}$ & $\begin{array}{l}\text { Natural } \\
\text { resource }\end{array}$ & Telecom & Utility \\
\hline Argentina & AR & 5 & 2 & 0 & 1 & 0 & 0 & 2 & 0 \\
\hline Australia & $\mathrm{AU}$ & 18 & 2 & 2 & 3 & 2 & 9 & 0 & 0 \\
\hline Germany & BD & 15 & 4 & 6 & 2 & 2 & 0 & 0 & 1 \\
\hline Belgium & BG & 3 & 0 & 1 & 1 & 0 & 1 & 0 & 0 \\
\hline Brazil & BR & 23 & 2 & 9 & 5 & 0 & 4 & 0 & 3 \\
\hline Colombia & $\mathrm{CB}$ & 3 & 2 & 1 & 0 & 0 & 0 & 0 & 0 \\
\hline China & $\mathrm{CH}$ & 3 & 1 & 2 & 0 & 0 & 0 & 0 & 0 \\
\hline Chile & $\mathrm{CL}$ & 10 & 1 & 0 & 3 & 1 & 0 & 2 & 3 \\
\hline Canada & $\mathrm{CN}$ & 42 & 3 & 14 & 7 & 1 & 13 & 3 & 1 \\
\hline Czech Rep & $\mathrm{CZ}$ & 1 & 1 & 0 & 0 & 0 & 0 & 0 & 0 \\
\hline Denmark & DK & 1 & 1 & 0 & 0 & 0 & 0 & 0 & 0 \\
\hline Spain & ES & 5 & 3 & 0 & 0 & 0 & 1 & 1 & 0 \\
\hline Finland & FN & 3 & 0 & 0 & 0 & 2 & 1 & 0 & 0 \\
\hline France & FR & 13 & 3 & 5 & 4 & 1 & 0 & 0 & 0 \\
\hline Greece & GR & 2 & 1 & 1 & 0 & 0 & 0 & 0 & 0 \\
\hline Hong Kong & HK & 45 & 15 & 12 & 9 & 6 & 0 & 0 & 3 \\
\hline Hungary & $\mathrm{HN}$ & 4 & 0 & 2 & 1 & 1 & 0 & 0 & 0 \\
\hline Indonesia & ID & 1 & 1 & 0 & 0 & 0 & 0 & 0 & 0 \\
\hline India & IN & 28 & 1 & 18 & 3 & 2 & 1 & 2 & 1 \\
\hline Ireland & IR & 5 & 3 & 1 & 1 & 0 & 0 & 0 & 0 \\
\hline Israel & IS & 2 & 0 & 0 & 2 & 0 & 0 & 0 & 0 \\
\hline Italy & IT & 4 & 1 & 0 & 2 & 0 & 0 & 1 & 0 \\
\hline Japan & JP & 20 & 2 & 8 & 9 & 1 & 0 & 0 & 0 \\
\hline Korea & KO & 12 & 3 & 5 & 3 & 0 & 0 & 0 & 1 \\
\hline Luxembourg & LX & 1 & 0 & 1 & 0 & 0 & 0 & 0 & 0 \\
\hline Mexico & MX & 10 & 1 & 4 & 3 & 1 & 1 & 0 & 0 \\
\hline Malaysia & MY & 4 & 0 & 1 & 2 & 1 & 0 & 0 & 0 \\
\hline Netherlands & NL & 10 & 4 & 2 & 3 & 0 & 1 & 0 & 0 \\
\hline Norway & NW & 5 & 0 & 3 & 0 & 1 & 1 & 0 & 0 \\
\hline Austria & $\mathrm{OE}$ & 7 & 1 & 2 & 1 & 0 & 2 & 0 & 1 \\
\hline Peru & $\mathrm{PE}$ & 2 & 0 & 1 & 0 & 0 & 0 & 1 & 0 \\
\hline Philippines & PH & 4 & 0 & 0 & 2 & 2 & 0 & 0 & 0 \\
\hline Poland & $\mathrm{PO}$ & 2 & 0 & 2 & 0 & 0 & 0 & 0 & 0 \\
\hline Portugal & PT & 1 & 0 & 1 & 0 & 0 & 0 & 0 & 0 \\
\hline Russia & RS & 2 & 0 & 0 & 0 & 0 & 0 & 2 & 0 \\
\hline South Africa & SA & 13 & 1 & 2 & 4 & 2 & 4 & 0 & 0 \\
\hline Sweden & SD & 4 & 1 & 1 & 0 & 0 & 1 & 1 & 0 \\
\hline Singapore & SG & 13 & 3 & 5 & 3 & 2 & 0 & 0 & 0 \\
\hline Slovenia & SJ & 1 & 0 & 0 & 0 & 1 & 0 & 0 & 0 \\
\hline Switzerland & SW & 7 & 2 & 3 & 1 & 1 & 0 & 0 & 0 \\
\hline Taiwan & TA & 19 & 3 & 14 & 2 & 0 & 0 & 0 & 0 \\
\hline Thailand & $\mathrm{TH}$ & 2 & 0 & 2 & 0 & 0 & 0 & 0 & 0 \\
\hline Turkey & TK & 3 & 0 & 2 & 1 & 0 & 0 & 0 & 0 \\
\hline UK & UK & 49 & 7 & 11 & 19 & 3 & 4 & 2 & 3 \\
\hline All & & 427 & 75 & 144 & 97 & 33 & 44 & 17 & 17 \\
\hline
\end{tabular}


Figure 1. Absolute Abnormal Returns and Abnormal Trading Volume Around Earnings Announcements Before and After US Listing for Emerging and Developed Market Firms

Absolute Abnormal Returns Around Earnings Announcements Before and After US Listing

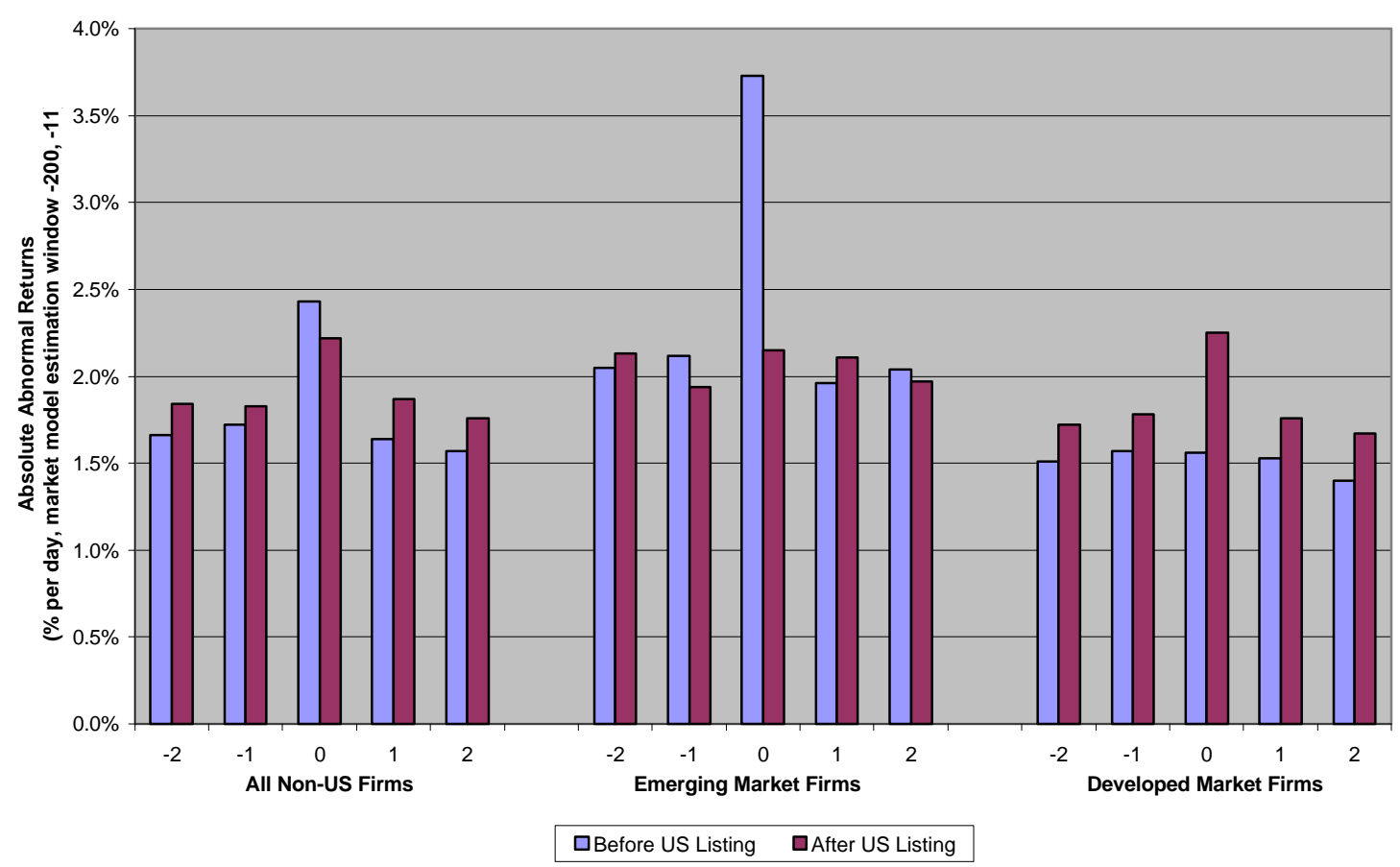

Abnormal Trading Volume Around Earnings Announcements Before and After US Listing

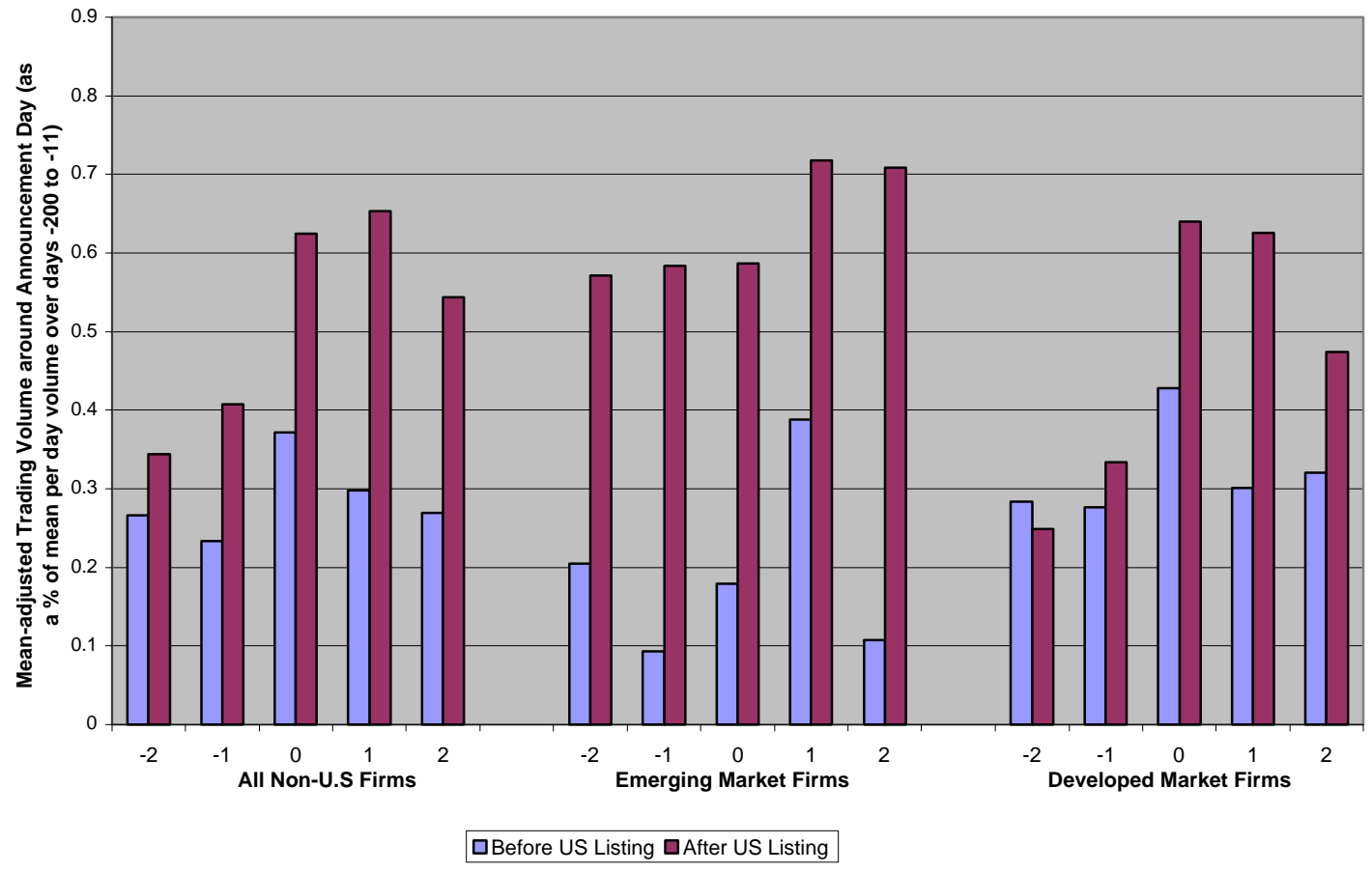


Figure 2. Absolute Abnormal Returns and Abnormal Trading Volume Around Earnings Announcements Before and After US Listing for Rule 144a, OTC and Exchange Listings

Absolute Abnormal Returns Around Earnings Announcements Before and After U.S. Listing

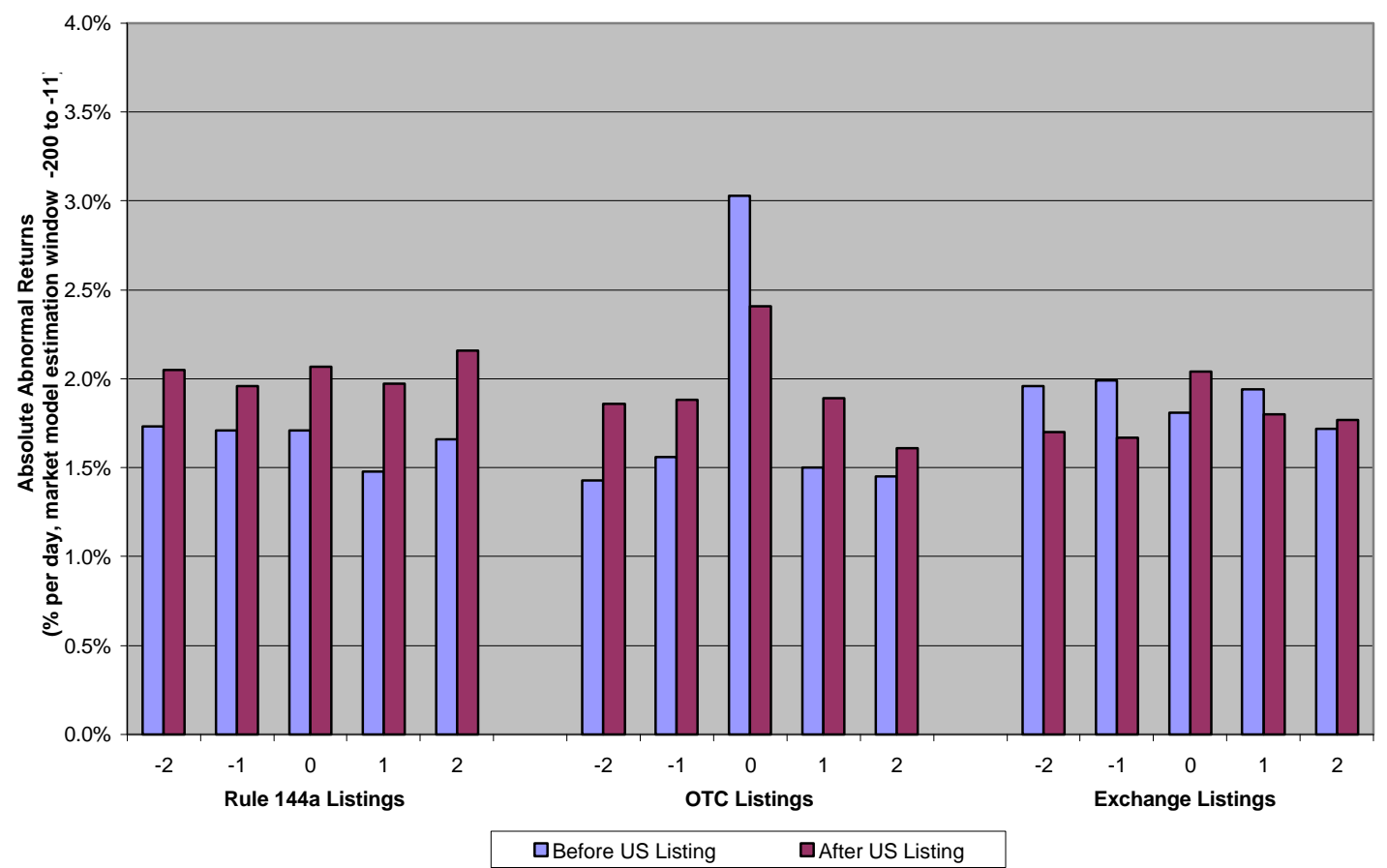

Abnormal Trading Volume Around Earnings Announcements Before and After US Listing

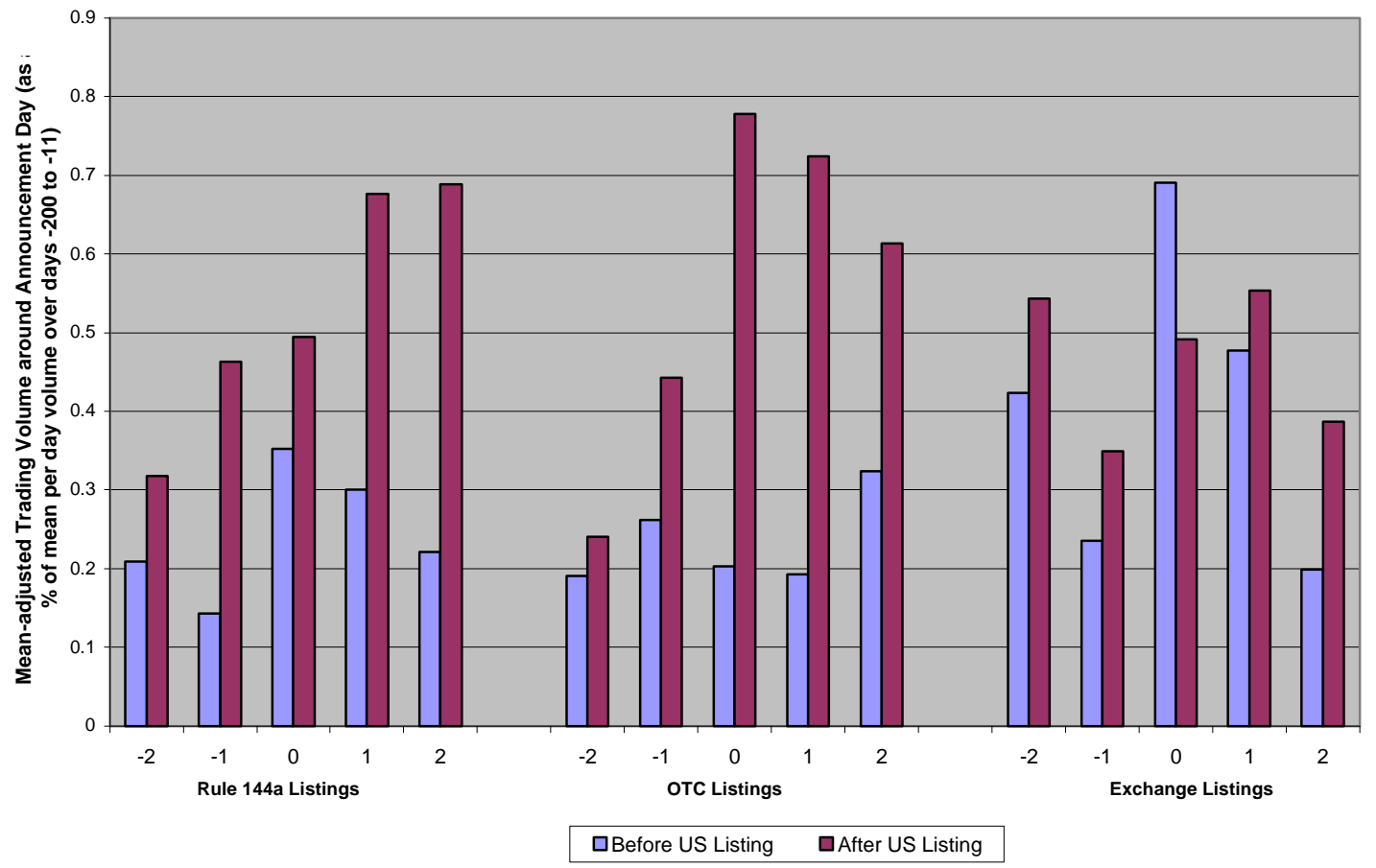

